\title{
Asymmetric organocatalytic Michael addition of Meldrum's acid to nitroalkenes: probing the mechanism of bifunctional thiourea organocatalysts
}

\author{
Antti O. Kataja and Ari M. P. Koskinen* \\ Department of Chemistry, Aalto University School of Science and Technology, \\ PO Box 16100, FI-00076 Aalto, Finland \\ E-mail:Ari.Koskinen@,tkk.fi
}

\begin{abstract}
The asymmetric Michael addition of Meldrum's acid to nitroalkenes was studied using a novel type of Cinchona alkaloid-based bifunctional thiourea organocatalyst. The functionality of the thiourea catalysts was also probed by preparing and testing thiourea- $N$-methylated analogues of the well-known bis-(3,5-trifluoromethyl)phenyl-substituted catalyst.
\end{abstract}

Keywords: Organocatalysis, Michael addition, bifunctional thiourea catalysts, Cinchona alkaloids, Meldrum's acid

\section{Introduction}

Enantioselective carbon-carbon bond formation is one of the lasting challenges in organic chemistry. Though well-established methods and strategies for stereocontrolled bond formation have been developed, the modern chemist should also consider 'green' values and hence avoid metal-based catalysis when possible. Thus asymmetric organocatalysis is in high demand and the subject of rigorous study. ${ }^{1}$ A relatively recent addition to the library of organocatalysts is the family of thiourea-based bifunctional catalysts that combine a hydrogen bond-donor with a tertiary amine attached to a chiral scaffold. Thiourea-based bifunctional catalysis has indeed been extensively studied in recent years, with a great number of reports showing its applicability to a wide range of reactions. ${ }^{2,3}$ The stereochemical potential of Cinchona alkaloids has also been successfully exploited in the elaboration of thiourea-based organocatalysts. ${ }^{4}$ Other recently reported Cinchona-based H-bond donor catalysts include squaramide ${ }^{5}$ and sulfonamide derivatives. $^{6}$

We recently developed a concise, enantioselective synthesis for $(S)$-pregabalin (Lyrica $\left.{ }^{\circledR}\right){ }^{7}$ The key stereoselective Michael addition of Meldrum's acid $\mathbf{1}$ to the nitroalkene precursor 2a was performed with a novel 9-amino-(9-deoxy)-epi-quinidine thiourea catalyst $\mathbf{3}$, which contains 
the sterically bulky trityl group as a thiourea substituent, instead of the widely used 3,5bis(trifluoromethyl)phenyl group. Moreover, the original Cinchona-derived catalyst 4, described independently and in rapid succession along with its close analogues by the groups of Chen, Sóos, Connon and Dixon, ${ }^{8}$ was found to be severely lacking in stereoinduction in the key step of the synthesis, in spite of complete conversion and a reasonable reaction time (eight hours in model studies). The Michael adduct 5a was attained using 3 with an enantiomeric excess of $75 \%$, whereas 4 gave an ee of only 32\% (Scheme 1). In this present study we set out to elaborate further the behavior of $\mathbf{3}$ in Michael addition reactions of Meldrum's acid to nitroalkenes. We also attempted to probe the general reactivity of thiourea-type catalysts by perturbing the bicoordinating ability of the thiourea moiety.

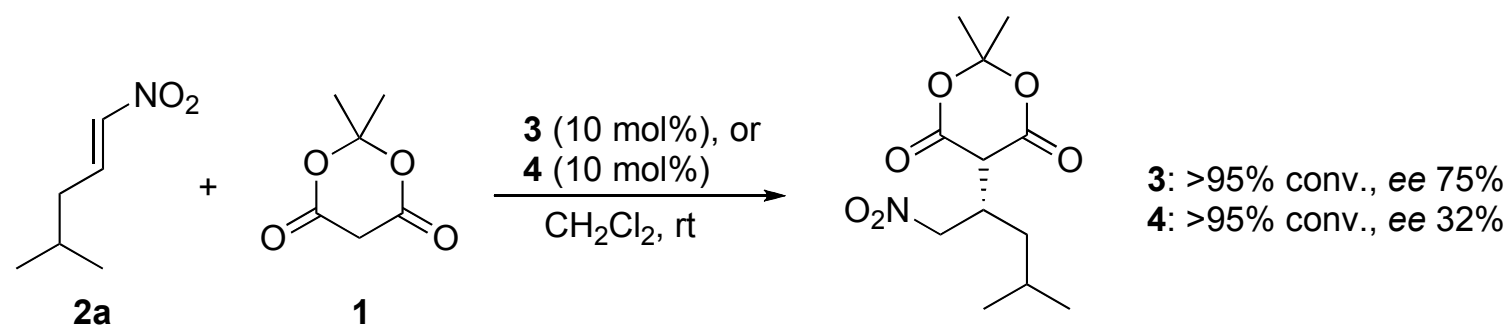

$5 a$

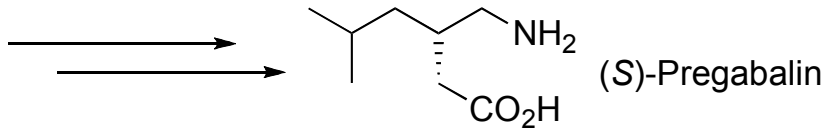<smiles>C=C1CN2CCC1CC2[C@H](NC(=S)NC(c1ccccc1)(c1ccccc1)c1ccccc1)c1ccnc2ccc(OC)cc12</smiles>

3<smiles>C=C1CN2CCC1C[C@H]2[C@H](NC(=S)Nc1cc(C(F)(F)F)cc(C(F)(F)F)c1)c1ccnc2ccc(OC)cc12</smiles>

4

Scheme 1. The key step in the synthesis of (S)-Pregabalin.

\section{Results and Discussion}

We began our study on the activity of $\mathbf{3}$ by performing solvent and substrate screening. The results for the solvent screen are shown in Table 1. There is little significant difference in enantioselectivity between $\mathrm{CH}_{2} \mathrm{Cl}_{2}, \mathrm{Et}_{2} \mathrm{O}$ and THF. $\mathrm{MeCN}$ gave a slightly lower selectivity, 
whereas with DMF asymmetric induction was nearly completely suppressed. This is more or less expected for a solvent that is a good hydrogen bond acceptor, as it would conceivably compete for the donor sites on the catalyst. Chlorobenzene was found to give a slightly higher enantioselectivity, but the incomplete and slow solubility of Meldrum's acid to chlorobenzene led us to complete the substrate screening using $\mathrm{CH}_{2} \mathrm{Cl}_{2}$.

Table 1. Solvent screening for 3

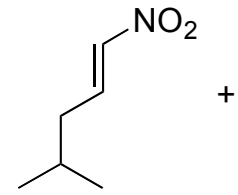

$2 a$<smiles>CC1(C)OC(=O)CC(=O)O1</smiles>

1

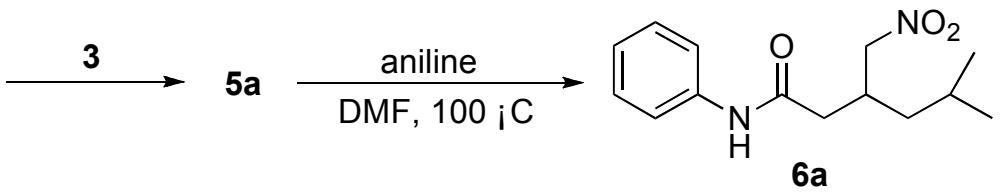

For determination of ee.

\begin{tabular}{ccccc} 
Entry & Solvent & Time $(\mathrm{h})$ & Conversion $(\%)^{\mathrm{a}}$ & $e e(\%)^{\mathrm{b}}$ \\
\hline 1 & $\mathrm{CH}_{2} \mathrm{Cl}_{2}$ & 10 & $>95$ & $72^{\mathrm{c}}$ \\
2 & $\mathrm{Et}_{2} \mathrm{O}$ & 21 & $>95$ & 69 \\
3 & $\mathrm{THF}$ & 18 & $>95$ & 72 \\
4 & $\mathrm{MeCN}$ & 17 & $>95$ & 56 \\
5 & $\mathrm{PhCl}$ & 16 & $>95$ & 78 \\
6 & $\mathrm{DMF}$ & 18 & $>95$ & 16 \\
\hline
\end{tabular}

Reaction conditions: $100 \mathrm{mg}(0.8 \mathrm{mmol})$ of nitroalkene, $200 \mathrm{~mol} \%$ of Meldrum's acid, $10 \mathrm{~mol} \%$ of 3, $0.5 \mathrm{~mL}$ solvent, rt. ${ }^{\mathrm{a}}$ Determined by ${ }^{1} \mathrm{H}$ NMR; ${ }^{\mathrm{b}}$ Determined by chiral HPLC of the anilide derivative 6a. ${ }^{9}{ }^{c}$ Result of model studies, actual synthesis of Ref. 7 gave $75 \%$ ee.

Meldrum's acid functions as a protected enol equivalent of acetic acid. Easy deprotection and further functionalization makes it an interesting nucleophile. ${ }^{10}$ However, examples of asymmetric reactions with Meldrum's acid as a nucleophile are scarce, and furthermore the reports have not been encouraging, as was previously shown by Kleczkowska and Sas ${ }^{11}$. They reported poor enantioselectivities in the Michael addition of Meldrum's acid to $\beta$-nitrostyrene $\mathbf{2 b}$, when catalyzed by Cinchona alkaloids or other chiral amines such as (-)-sparteine or (-)brucine. Takemoto also reported mediocre enantioselectivity for the well-known Takemoto's catalyst in this reaction. ${ }^{12}$ In a control experiment, we measured an ee of $31 \%$ when catalyst 4 was used.

For catalyst 3, we likewise found that the reaction between Meldrum's acid and aromatic and heteroaromatic nitroalkenes uniformly gave mediocre enantioselectivities with no clear trends based on electronic properties of the aromatic ring, as shown in Table 2. Surprisingly, aliphatic substrates turned out to give slightly higher selectivities, though with ample room for further improvement. This seems to be a reversal of the common tendency of aliphatic nitroalkenes to give poorer stereoselectivity in thiourea-catalyzed nitro-Michael additions. ${ }^{8 c, d}$ Thus Meldrum's 
acid does not seem to function well with chiral bifunctional catalysts, and a different solution to establishing its use as a nucleophile in asymmetric synthesis awaits discovery (see Ref. 7 for a screening of different thiourea catalysts).

Table 2. Substrate screening for $\mathbf{3}$

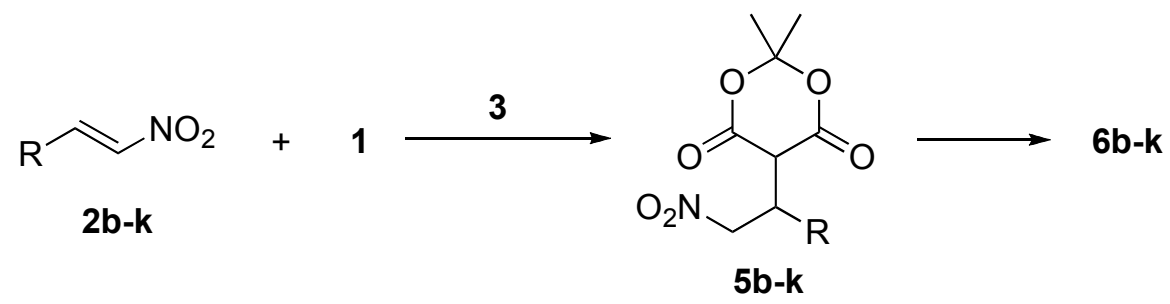

\begin{tabular}{clccc} 
Entry & \multicolumn{1}{c}{$\mathrm{R}$} & Time (h) & Conversion $(\%)^{\mathrm{a}}$ & $E e(\%)^{\mathrm{b}}$ \\
\hline 1 & $\mathrm{Ph}(\mathbf{2 b})$ & 8 & $>95$ & 49 \\
2 & $4-\mathrm{MeOC}_{6} \mathrm{H}_{4}(\mathbf{2 c})$ & 9 & $>95$ & 53 \\
3 & $3-\mathrm{MeOC}_{6} \mathrm{H}_{4}(\mathbf{2 d})$ & 12 & $>95$ & 55 \\
4 & $4-\mathrm{BrC}_{6} \mathrm{H}_{4}(\mathbf{2 e})$ & 17 & $>95$ & 57 \\
5 & $3-\mathrm{BrC}_{6} \mathrm{H}_{4}(\mathbf{2 f})$ & 8 & $>95$ & 47 \\
6 & $2-$ furyl (2g) & 9 & $>95$ & 47 \\
7 & 3 -furyl (2h) & 9 & $>95$ & 48 \\
8 & $\mathrm{Cy}(\mathbf{2 i})$ & 49 & 91 & 59 \\
9 & $n-\mathrm{C}_{5} \mathrm{H}_{11}(\mathbf{2 j})$ & 19 & $>95$ & 68 \\
10 & BnOCH $_{2}(\mathbf{2 k})$ & 7 & $>95$ & 62 \\
\hline
\end{tabular}

Reaction conditions: $0.8 \mathrm{mmol}$ nitroalkene, $1.6 \mathrm{mmol}$ of Meldrum's acid, $10 \mathrm{~mol} \%$ of $\mathbf{1}, 0.5 \mathrm{~mL}$ $\mathrm{CH}_{2} \mathrm{Cl}_{2}$, rt. ${ }^{\text {a }}$ Determined by ${ }^{1} \mathrm{H}$ NMR; ${ }^{\mathrm{b}}$ Determined by chiral HPLC of the anilide derivatives 6b-k.

However, the real surprise was the complete inactivity of $\mathbf{3}$ in the reaction between dimethyl malonate (7) and $\beta$-nitrostyrene. After 48 hours, racemic 8 was isolated in $14 \%$ yield, presumably the result of a slow background reaction (Scheme 2). With acetylacetone 9 as the nucleophile, a comparable reaction gave $\mathbf{1 0}$ in $45 \%$ yield with an ee slightly below $50 \%$. For comparison, when catalyzed by 4 the reaction gave complete conversion in eight hours and an $e e$ of $85 \%$. 


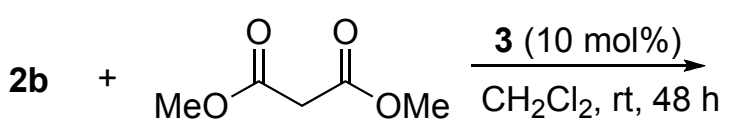

7

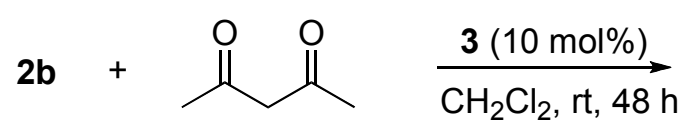

9<smiles>COC(=O)C(C(=O)OC)C(C[N+](=O)[O-])c1ccccc1</smiles>

8<smiles>CC(=O)C(C(C)=O)C(C[N+](=O)[O-])c1ccccc1</smiles>

10

Scheme 2. Activity of $\mathbf{3}$ with common 1,3-dicarbonyl nucleophiles.

Before addressing the question of this inactivity, the mechanism of bifunctional thiourea catalysts should be discussed briefly. The widely accepted qualitative rationalization presented e.g. by Takemoto et al. assumes the electrophile to be activated via H-bond assisted coordination of the nitro group to the thiourea (Scheme 3). ${ }^{12 \mathrm{~b}}$ The protonated tertiary amine then directs the nucleophile to attack from the less hindered face. In a theoretical study, Pápai and Sóos showed ${ }^{13}$ that while calculations do support this, and also explain the preferred stereochemistry of the product, an opposite coordination scheme is not only possible, but in fact energetically slightly more favorable.
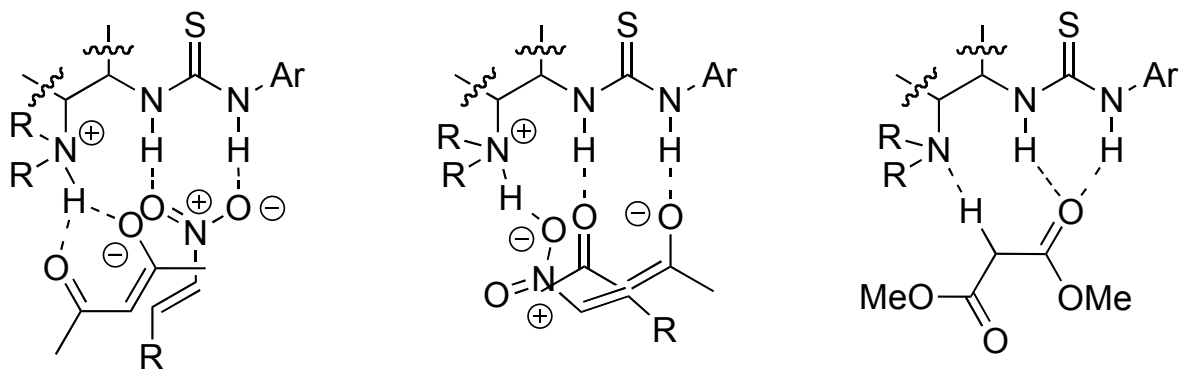

Scheme 3. Possible coordination schemes of the catalyst-nucleophile-electrophile ternary complex according to Takemoto (left), Soós (middle), and nucleophile deprotonation (right).

Takemoto $^{11 \mathrm{~b}}$ and Jacobsen ${ }^{14}$ have also recently published X-ray structures of their respective thiourea catalysts. In both cases the thiourea $\mathrm{N}-\mathrm{H}$ protons are found in a trans-conformation with respect to the sulfur atom across the $\mathrm{N}-\mathrm{C}_{\mathrm{sp} 2}$ bond. Conversely, in our earlier study the thiourea moiety was found to be in trans/cis-form for a phenylfluorenyl-substituted Cinchona-thiourea catalyst. $^{7}$ A general survey of published thiourea crystal structures revealed that the trans/cis form is by far preferred in solid state, with less than $20 \%$ of published compounds showing 
trans/trans-conformation. ${ }^{15}$ Though solid state structures obviously do not directly correlate with solvated structures, it is possible that the additional demand of energy for finding the optimal conformation would pose problems for catalysts with substituents that force the thiourea moiety to retain its trans/cis-conformation.

The unusually high acidity of Meldrum's acid ( $\mathrm{p} K_{\mathrm{a}} 4.97$ in $\mathrm{H}_{2} \mathrm{O}, 7.32$ in DMSO) ${ }^{16}$ shows that it can be deprotonated by an amine alone, as shown by the use of e.g. (-)-sparteine as a chiral base in the Michael addition (see above). The tertiary amine ( $K_{\mathrm{aH}} 11 / 9.8$ in $\mathrm{H}_{2} \mathrm{O} / \mathrm{DMSO}$ ) of the Cinchona-type thiourea catalysts might not be basic enough for the deprotonation of less acidic nucleophiles. Coordination to the thiourea H-bond donor sites is required to acidify the $\alpha$-proton sufficiently for deprotonation to take place. In the case of $\mathbf{3}$, either insufficient acidity of the thiourea N-H protons and thus their poorer ability to act as H-bond donors, or steric clashes from the bulky trityl substituent could account for the inactivity of the catalyst with regard to dimethyl malonate.

To investigate this, the 'Southern' substituent of the thiourea moiety was changed from trityl to cyclohexyl to give catalyst 11, which (like $\mathbf{3}$ ) has a significantly less acidic thiourea moiety than $\mathbf{4}$, and is sterically less demanding than $\mathbf{3}$. Catalyzed by $\mathbf{1 1}$, the reaction of dimethyl malonate and nitrostyrene gave 8 in $73 \%$ yield after 24 hours, with an ee of $73 \%$ (Scheme 4). Thus it seems that neither the acidity of thiourea $\mathrm{N}-\mathrm{Hs}$ nor of the dimethyl malonate $\alpha$-proton is a main factor for the inactivity of $\mathbf{3}$.

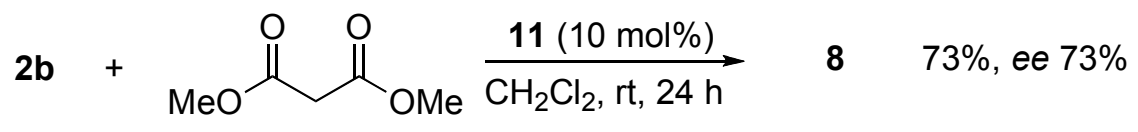

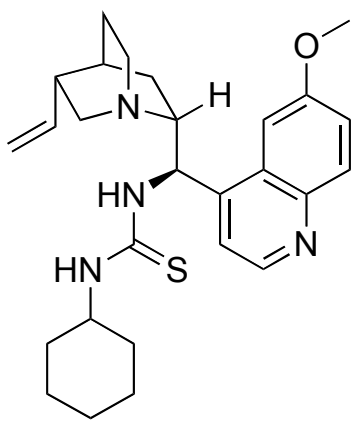

11

Scheme 4. Reaction of dimethyl malonate and nitrostyrene catalyzed by 11 .

The general mechanistic assumptions of bifunctional thiourea catalysts are based on the 1,3dicarbonyl nucleophile deprotonation taking place on the more acidic enol form. There are practically no reports on the enolization constants of malonate diesters, and they are usually found to contain no enol form in solution (an $\mathrm{NMR}$ evaluation in $\mathrm{CD}_{2} \mathrm{Cl}_{2}$ confirmed this). Hence the tentative conclusion is that the steric bulk of the trityl group disrupts crucial H-bond 
coordination and $\alpha$ proton acidification between dimethyl malonate and $\mathbf{3}$, thus strongly suppressing the deprotonation step. On the other hand, acetylacetone is normally enolized to a considerable extent, especially in nonpolar solvents, stabilized by the formation of an intramolecular H-bond. ${ }^{17}$ This, together with the difference of several $\mathrm{p} K_{\mathrm{a}}$ units in the respective acidities of acetylacetone and dimethyl malonate $\alpha$ protons (9/13.3 vs. 13/15.9 $\mathrm{H}_{2} \mathrm{O} / \mathrm{DMSO}$ ) makes the former significantly easier to deprotonate, which most likely accounts for the difference in activities.

A recent report suggested that the bicoordinating ability of the H-bond donor site is not completely essential; according to a study by $\mathrm{Lu}^{6}{ }^{6}$ the sulfonamide analogues of Cinchonaderived thiourea catalysts are quite able to catalyze the Michael reaction of $\beta$-ketoesters and nitroalkenes. We set out to test how the perturbation of the bicoordinating ability of the thiourea affects the activity of the catalyst. Based on the results of $\mathrm{Lu}$, our tentative hypothesis was that perhaps one site would be enough, and this site should be closer to the Cinchona backbone to allow for interaction with the tertiary amine. This was examined by modifying the structure of 4 in order to prepare derivatives $\mathbf{1 2}$ and $\mathbf{1 3}$, in which both H-bond donors of the thiourea group are in turn substituted with methyl groups.

The catalysts were prepared by condensation of the corresponding isothiocyanate and methylated amine (Scheme 5). The free amine $\mathbf{1 4}$ was prepared according to a slightly modified method of Brunner. ${ }^{718}$ The methylated catalyst $\mathbf{1 2}$ was prepared by first forming the corresponding ethyl carbamate $\mathbf{1 5}$ from $\mathbf{1 4}$. The carbamate was subjected to $\mathrm{LiAlH}_{4}$ reduction to attain the amine 16, which was subsequently condensed with 3,5-bis(trifluoromethyl)phenyl isothiocyanate. Catalyst $\mathbf{1 3}$ was prepared via reversing the original route. The free amine $\mathbf{1 4}$ was converted into the corresponding isothiocyanate $\mathbf{1 7}$ in good yield. ${ }^{7}$ The methylated aniline $\mathbf{1 8}$ was easily prepared from the commercially available 3,5-bis(trifluoromethyl)aniline via trifluoroacetylation, methylation and hydrolysis, giving a practically pure product in excellent yield. ${ }^{19}$ The condensation step was found to be somewhat problematic, since $\mathbf{1 8}$ is an extremely electron-poor nucleophile. Catalyst 13 was obtained by deprotonating 18 with $n$-BuLi at $-78{ }^{\circ} \mathrm{C}$ and then adding the isothiocyanate dissolved in DMF. 


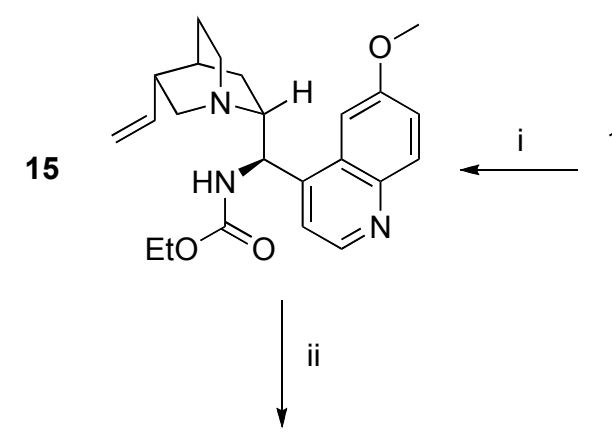<smiles>C=CC1CC2CC1CN2[C@H](N=C=S)c1ccnc2ccc(OC)cc12</smiles><smiles>C#CCC1CN2CCC1C2[C@H](NC)c1ccnc2ccc(OC)cc12</smiles><smiles>C=CC1CN2CCC1CC2[C@H](c1ccnc2ccc(OC)cc12)N(C)C(=S)Nc1cc(C(F)(F)F)cc(C(F)(F)F)c1</smiles>

12<smiles>[V]C1CC1</smiles><smiles>C=CC1C2CCN1C([C@H](NC(=S)N(C)c1cc(C(F)(F)F)cc(C(F)(F)F)c1)c1ccnc3ccc(OC)cc13)C2</smiles>

13<smiles>CNc1cc(C(F)(F)F)cc(C(F)(F)F)c1</smiles>

18

Scheme 5. Synthesis of thiourea- $N$-methylated catalysts. Reagents and conditions: i) EtOCOCl, $\mathrm{Et}_{3} \mathrm{~N}, \mathrm{CH}_{2} \mathrm{Cl}_{2}, \mathrm{rt}(53 \%)$ ii) $\mathrm{LiAlH}_{4}, \mathrm{THF}, 0{ }^{\circ} \mathrm{C}$ to $\mathrm{rt}(51 \%)$. iii) 3,5-bis(trifluoromethyl)phenyl isothiocyanate, THF, $\mathrm{rt}(71 \%)$. iv) $\mathrm{CS}_{2}$, DCC, THF, $-15{ }^{\circ} \mathrm{C}$ to $\mathrm{rt}(74 \%)$. v) $n$-BuLi, 18, THF, $\mathrm{DMF},-78{ }^{\circ} \mathrm{C}$ to $\mathrm{rt}(49 \%)$. vi) TFAA, $\mathrm{CH}_{2} \mathrm{Cl}_{2}, 0{ }^{\circ} \mathrm{C}$ to rt. vii) MeI, acetone, rfx. viii) $\mathrm{MeOH}: \mathrm{H}_{2} \mathrm{O}$ $(5: 1), \mathrm{K}_{2} \mathrm{CO}_{3}$, rt (90\% over 3 steps).

We fond that, for both compounds $\mathbf{1 2}$ and 13, the catalytic activity was strongly diminished. After 48 hours the product was isolated in $36 \%$ and $45 \%$ yields, respectively, with practically no asymmetric induction. Hence this would seem to confirm that the bicoordinating ability is crucial for the functioning of thiourea-based catalysts (Scheme 6).

$$
2 b+\mathrm{MeO}_{\mathrm{OMe}} \frac{\mathrm{a}) \mathrm{vs} . \mathrm{b})}{\mathrm{CH}_{2} \mathrm{Cl}_{2}, \mathrm{rt}, 48 \mathrm{~h}}
$$

Scheme 6. Model reaction with catalysts 12 and 13.

a) $36 \%$, ee $13 \%$

b) $45 \%$, ee $-13 \%$ 
There are other reports probing the activity of bifunctional thiourea catalysts by adding, blocking or removing additional hydrogen bond donor sites. Wang reported that catalyst activity in nitro-Michael addition is significantly boosted by addition of $\mathrm{H}$-bond donor sites (19, 20), giving improved yields and enantioselectivities. ${ }^{20}$ Conversely, the enantioselectivity is significantly eroded when the additional coordination sites around the thiourea moiety are blocked or removed. In another study, Liang and Ye tested a hybrid Cinchona-thiourea catalyst 21 in which chiral 1,2-diaminocyclohexane was used as the other thiourea substituent, thus incorporating an additional primary amine in the catalyst structure. ${ }^{21}$ The catalyst was found to be effective in Michael addition of diethyl malonate to both cyclic and open chain enones. Dimethylation of the free amino group completely suppressed the catalytic activity, but the authors did not further address the mechanistic questions this raises.

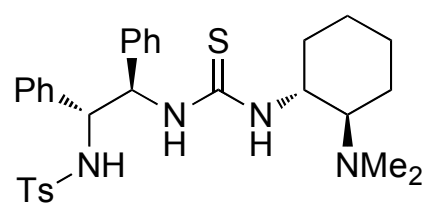

19

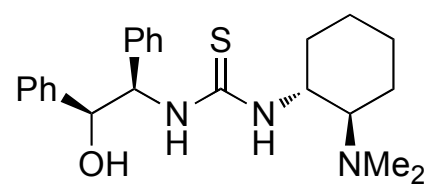

20

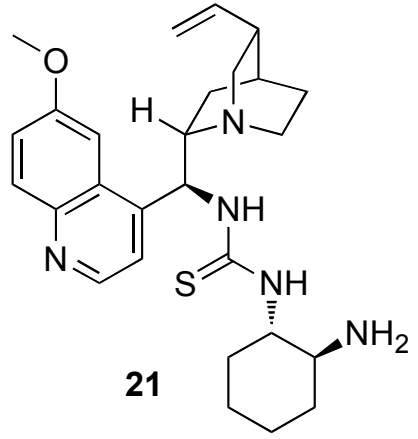

Scheme 7. Catalysts with additional H-bond donor sites.

\section{Conclusions}

Chiral bifunctional thiourea organocatalysts are a new and effective way to conduct asymmetric $\mathrm{C}-\mathrm{C}$-bond formation. Among the several promising examples are Cinchona-alkaloid derived thiourea catalysts that have been found to be effective in a wide range of reactions. In this study we have elaborated the activity of a novel trityl-substituted 9-amino-(9-deoxy)epi-quinidine thiourea catalyst and the properties of Meldrum's acid as a nucleophile in asymmetric Michael addition. Furthermore, we have probed the functionality of Cinchona-derived thiourea catalysts in general by preparing and testing $N$-methylated thiourea analogues. Blocking the thiourea $\mathrm{N}-$ $\mathrm{H}$-sites with methyl groups led to severe lack of catalytic activity in the Michael-addition of dimethyl malonate to $\beta$-nitrostyrene, thus underlining the importance of the bicoordinating $\mathrm{H}$ bond donor functionality for bifunctional thiourea-tertiary amine catalysts. 


\section{Experimental Section}

General. Reagents were used as purchased from suppliers, unless otherwise indicated. Dry solvents $\left(\mathrm{CH}_{2} \mathrm{Cl}_{2}\right.$, THF, $\left.\mathrm{Et}_{2} \mathrm{O}, \mathrm{MeCN}\right)$ were obtained with MBraun MB-SPS 800 solvent drying system. Chlorobenzene was distilled from $\mathrm{P}_{2} \mathrm{O}_{5}$ on $4 \AA$ molecular sieves. Reactions requiring inert conditions were performed in flame-dried glassware under a positive pressure of argon. The nitroalkenes were synthesized from corresponding aldehyde and nitromethane by Henry reactions (2b-c, $\mathbf{2} \mathbf{f}-\mathbf{k})$, followed by elimination in case of aliphatic substrates, or by Knoevenagel condensation (2d-e). Compounds 3, 4, 5a, 6a, 14 and 17 were synthesized according to published methods ${ }^{7,8}$ and spectral data was found to correspond with literature. Spectral data for $\mathbf{5 b}$ and $\mathbf{5 c},^{22} \mathbf{8}^{23}$ and $\mathbf{1 0}^{24}$ was found to correspond with literature data. Reactions were monitored by thin layer chromatography using $\mathrm{SiO}_{2}$ (silica gel $60 \mathrm{~F}_{254}$, Merck, coated aluminum plates), and visualizing by UV light or by aqueous $\mathrm{KMnO}_{4}$ or ninhydrin solutions. Flash chromatography was carried out on $\mathrm{SiO}_{2}$ (silica gel $60 \mathrm{~F}_{254}, 230-400$ mesh ASTM, Merck). ${ }^{1} \mathrm{H}$ and ${ }^{13} \mathrm{C}$ NMR spectra were recorded with a Bruker Avance $400\left({ }^{1} \mathrm{H}: 399.98 \mathrm{MHz} ;{ }^{13} \mathrm{C}: 100.59\right.$ $\mathrm{MHz}$ ) spectrometer. Chemical shifts are reported in ppm relative to TMS internal standard ( $\delta=$ $0.00)$ in $\mathrm{CDCl}_{3}$, or residual solvent signal in MeOD-d $(\delta=3.31)$ for ${ }^{1} \mathrm{H}$ NMR spectra. For ${ }^{13} \mathrm{C}$ NMR spectra, solvent residual peaks ( $\delta=77.0 \mathrm{ppm}$ for $\mathrm{CDCl}_{3}, \delta=49.0 \mathrm{ppm}$ for MeOD-d ( $_{4}$ ) were used as internal standards. Abbreviation of multiplicities is as follows: s (singlet), $d$ (doublet), $t$ (triplet), q (quadruplet), $\mathrm{m}$ (multiplet). The prefix br is used when the signal is broadened, and app when the signal resolution is not good enough to determine the true multiplicity (e.g. dd becomes t). High-resolution mass spectrometric data was recorded with Waters LCT Premierspectrometer at Helsinki University of Technology. IR spectra were recorded with Perkin-Elmer Spectrum One FTIR instrument. Optical rotations were obtained with a Perkin-Elmer 343 polarimeter $(\lambda=589 \mathrm{~nm})$ using a $1 \mathrm{dm}$ cell. Chiral HPLC analysis was performed with Waters 501 pump and Waters UV 2487 dual absorbance detector. The exact conditions are reported in connection with each analyzed substance. HPLC analyses were performed before crystallization steps to exclude possible additional enantioenrichment. Elemental analyses were performed with Perkin-Elmer (PE) 2400 Series II CHNS/O Analyzer. Melting points were recorded with Stuart SMP3 melting point apparatus in open capillary tubes.

\section{General procedure for screening reactions}

Nitroalkene $(0.8 \mathrm{mmol}, 100 \mathrm{~mol} \%)$ was loaded in a small vial equipped with a magnetic stirrer. Compound 1 (230 mg, $1.6 \mathrm{mmol}, 200 \mathrm{~mol} \%)$ was added, and the mixture was dissolved in $\mathrm{CH}_{2} \mathrm{Cl}_{2}(0.5 \mathrm{~mL})$. Catalyst $3(50 \mathrm{mg}, 0.08 \mathrm{mmol}, 10 \mathrm{~mol} \%$ ) was added, the vial was capped and the mixture was stirred at room temperature until completion. The solvents were evaporated and the crude mixture analyzed by ${ }^{1} \mathrm{H}$ NMR and used as such in the derivatization step.

5-(1-(3-Methoxyphenyl)-2-nitroethyl)-2,2-dimethyl-1,3-dioxane-4,6-dione (5d). Prepared according to the general procedure. Purification of a small sample for analytical purposes by 
flash chromatography (10\% MeOH in EtOAc) gave 5d as a yellowish oil. $\mathrm{R}_{f}=0.21$ (EtOAc); IR (neat): 2997, 2941, 1734, 1572, 1403, 1375, $1261 \mathrm{~cm}^{-1}$; ${ }^{1} \mathrm{H}$ NMR (MeOD-d, $400 \mathrm{MHz}$ ): NB! Dicarbonyl $\alpha$ proton not visible. Compounds $\mathbf{5 b}-\boldsymbol{k}$ are completely enolized in MeOD- $d_{4} . \delta 7.12$ $(\mathrm{t}, J=7.9 \mathrm{~Hz}, 1 \mathrm{H}), 7.03(\mathrm{~s}, 1 \mathrm{H}), 6.98(\mathrm{~d}, J=7.6 \mathrm{~Hz}, 1 \mathrm{H}), 6.69(\mathrm{dd}, J=8.1,2.0 \mathrm{~Hz}, 1 \mathrm{H}), 5.21$ (dd, $J=12.0,8.7 \mathrm{~Hz}, 1 \mathrm{H}), 5.07$ (dd, $J=11.9,7.5 \mathrm{~Hz}, 1 \mathrm{H}), 4.74(\mathrm{t}, J=8.1 \mathrm{~Hz}, 1 \mathrm{H}), 3.74(\mathrm{~s}, 3 \mathrm{H})$, $1.54(\mathrm{~s}, 6 \mathrm{H}) ;{ }^{13} \mathrm{C}$ NMR $\left(\mathrm{MeOD}-\mathrm{d}_{4}, 100 \mathrm{MHz}\right): \delta 169.2,160.9,145.3,129.9,121.2,114.4,112.8$, 102.8, 79.2, 76.5, 55.5, 41.3, 25.8; HRMS m/z 346.0906 $\left[\mathrm{C}_{15} \mathrm{H}_{17} \mathrm{NO}_{7}(\mathrm{M}+\mathrm{Na})^{+}\right.$requires 346.0903].

5-(1-(4-Bromophenyl)-2-nitroethyl)-2,2-dimethyl-1,3-dioxane-4,6-dione (5e). Prepared according to the general procedure. Purification of a small sample for analytical purposes by flash chromatography $\left(10 \% \mathrm{MeOH}\right.$ in EtOAc) gave 5e as a yellow oil. $\mathrm{R}_{f}=\mathrm{IR}$ (neat): 2994, 1716, 1579, 1488, 1399, 1374, $1262 \mathrm{~cm}^{-1}$; ${ }^{1} \mathrm{H}$ NMR (MeOD-d, $400 \mathrm{MHz}$ ): NB! Dicarbonyl $\alpha$

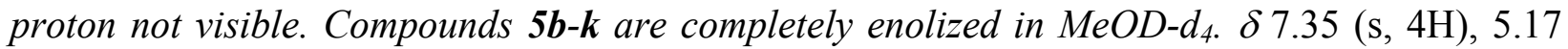
$(\mathrm{dd}, J=12.1,8.6 \mathrm{~Hz}, 1 \mathrm{H}), 5.09(\mathrm{dd}, J=12.1,7.7 \mathrm{~Hz}, 1 \mathrm{H}), 4.73(\mathrm{dd}, J=8.4,8.0 \mathrm{~Hz}, 1 \mathrm{H}), 1.53$ (s, $6 \mathrm{H}) ;{ }^{13} \mathrm{C}$ NMR (MeOD-d $\left.4,100 \mathrm{MHz}\right): \delta 169.1,161.2,143.1,132.0,130.9,120.7,102.9,78.8$, 76.3, 61.5, 40.9, 25.8; HRMS m/z 415.9742/417.9731 $\left[\mathrm{C}_{14} \mathrm{H}_{14} \mathrm{BrNO}_{6}(\mathrm{M}-\mathrm{H}+2 \mathrm{Na})^{+}\right.$requires 415.9722/417.9702].

5-(1-(3-Bromophenyl)-2-nitroethyl)-2,2-dimethyl-1,3-dioxane-4,6-dione (5f). Prepared according to the general procedure. Purification of a small sample for analytical purposes by flash chromatography (10\% $\mathrm{MeOH}$ in EtOAc) gave 5f as a yellow oil. $\mathrm{R}_{f}=\mathrm{IR}$ (neat): 2994, 2941, 1719, 1578, 1402, 1375, $1262 \mathrm{~cm}^{-1}$; ${ }^{1} \mathrm{H}$ NMR (MeOD- $d_{4}, 400 \mathrm{MHz}$ ): NB! Dicarbonyl $\alpha$ proton not visible. Compounds $\mathbf{5} \boldsymbol{b}$ - $\boldsymbol{k}$ are completely enolized in MeOD-d.$\delta 7.61(\mathrm{t}, J=1.8 \mathrm{~Hz}$, $1 \mathrm{H}), 7.39$ (d, $J=7.7 \mathrm{~Hz}, 1 \mathrm{H}), 7.28$ (ddd, $J=8.0,1.9,1.0 \mathrm{~Hz}, 1 \mathrm{H}), 7.14$ (t, $J=7.8 \mathrm{~Hz}, 1 \mathrm{H}), 5.19$ $(\mathrm{dd}, J=12.2,8.6 \mathrm{~Hz}, 1 \mathrm{H}), 5.10(\mathrm{dd}, J=12.1,7.7 \mathrm{~Hz}, 1 \mathrm{H}), 4.74(\mathrm{t}, J=8.1 \mathrm{~Hz}, 1 \mathrm{H}), 1.54(\mathrm{~s}, 6 \mathrm{H})$; ${ }^{13} \mathrm{C}$ NMR (MeOD-d $\left.4,100 \mathrm{MHz}\right): \delta 169.1,146.4,131.9,130.7,130.2,127.7,123.0,102.9,78.8$, 76.1, 41.1, 25.8; HRMS $m / z \quad 415.9731 / 417.9722 \quad\left[\mathrm{C}_{14} \mathrm{H}_{14} \mathrm{BrNO}_{6} \quad(\mathrm{M}-\mathrm{H}+2 \mathrm{Na})^{+}\right.$requires 415.9722/417.9702].

5-(1-(Furan-2-yl)-2-nitroethyl)-2,2-dimethyl-1,3-dioxane-4,6-dione (5g). Prepared according to the general procedure. Purification of a small sample for analytical purposes by flash chromatography $\left(10 \% \mathrm{MeOH}\right.$ in EtOAc) gave 5g as a yellow oil. $\mathrm{R}_{f}=$ IR (neat): 2995, 2943, 1731, 1578, 1411, 1375, $1262 \mathrm{~cm}^{-1}$; ${ }^{1} \mathrm{H}$ NMR (MeOD-d, $400 \mathrm{MHz}$ ): NB! Dicarbonyl a proton not visible. Compounds $\mathbf{5 b}-\boldsymbol{k}$ are completely enolized in MeOD-d $. \delta 7.31(\mathrm{~m}, 1 \mathrm{H}), 6.26(\mathrm{dd}, J=$ $3.2,1.9 \mathrm{~Hz}, 1 \mathrm{H}), 6.08(\mathrm{dt}, J=3.1,0.9 \mathrm{~Hz}, 1 \mathrm{H}), 5.06(\mathrm{dd}, J=11.9,8.8 \mathrm{~Hz}, 1 \mathrm{H}), 5.02$ (dd, $J=$ $11.8,6.9 \mathrm{~Hz}, 1 \mathrm{H}), 4.89-4.84(\mathrm{~m}, 1 \mathrm{H}), 1.58(\mathrm{~s}, 6 \mathrm{H}) ;{ }^{13} \mathrm{C} \mathrm{NMR}\left(\mathrm{MeOD}-\mathrm{d}_{4}, 100 \mathrm{MHz}\right): \delta 169.0$, 161.2, 156.3, 141.9, 111.1, 106.5, 102.9, 77.4, 73.8, 35.9, 25.8; HRMS $m / z 306.0582$ $\left[\mathrm{C}_{12} \mathrm{H}_{13} \mathrm{NO}_{7}(\mathrm{M}+\mathrm{Na})^{+}\right.$requires 306.0590].

5-(1-(Furan-3-yl)-2-nitroethyl)-2,2-dimethyl-1,3-dioxane-4,6-dione (5h). Prepared according to the general procedure. Purification of a small sample for analytical purposes by flash chromatography $\left(10 \% \mathrm{MeOH}\right.$ in EtOAc) gave $\mathbf{5 h}$ as a yellow oil. $\mathrm{R}_{f}=\mathrm{IR}$ (neat): 2994, 1737, 1578, 1555, 1377, $1261 \mathrm{~cm}^{-1}$; ${ }^{1} \mathrm{H}$ NMR (MeOD-d4, $400 \mathrm{MHz}$ ): NB! Dicarbonyl $\alpha$ proton not 
visible. Compounds $\mathbf{5 b}$ - $\boldsymbol{k}$ are completely enolized in MeOD- $d_{4} . \delta 7.32(\mathrm{~m}, 2 \mathrm{H}), 6.46(\mathrm{~s}, 1 \mathrm{H}), 5.05$ (dd, $J=11.6,8.7 \mathrm{~Hz}, 1 \mathrm{H}), 4.94(\mathrm{dd}, J=11.6,7.6 \mathrm{~Hz}, 1 \mathrm{H}), 4.66(\mathrm{t}, J=8.1 \mathrm{~Hz}, 1 \mathrm{H}), 1.55(\mathrm{~s}, 6 \mathrm{H})$; ${ }^{13} \mathrm{C}$ NMR (MeOD-d $\left.4,100 \mathrm{MHz}\right): \delta 169.0,161.2,143.3,140.5,126.9,111.7,102.8,79.1,75.6$, 33.0, 25.8; HRMS $m / z 306.0601\left[\mathrm{C}_{12} \mathrm{H}_{13} \mathrm{NO}_{7}(\mathrm{M}+\mathrm{Na})^{+}\right.$requires 306.0590].

5-(1-Cyclohexyl-2-nitroethyl)-2,2-dimethyl-1,3-dioxane-4,6-dione (5i). Prepared according to the general procedure. Purification of a small sample for analytical purposes by flash chromatography $\left(10 \% \mathrm{MeOH}\right.$ in EtOAc) gave 5i as a clear oil. $\mathrm{R}_{f}=0.13(50 \%$ EtOAc in hexane); IR (neat): 2994, 2926, 2852, 1731, 1575, 1406, 1373, $1260 \mathrm{~cm}^{-1}$; ${ }^{1} \mathrm{H}$ NMR (MeOD- $d_{4}$, $400 \mathrm{MHz}$ ): NB! Dicarbonyl $\alpha$ proton not visible. Compounds $\mathbf{5} \boldsymbol{b}$ - $\boldsymbol{k}$ are completely enolized in $\mathrm{MeOD}-d_{4} . \delta 4.90$ (app. t, $\left.J=10.8 \mathrm{~Hz}, 1 \mathrm{H}\right), 4.62$ (dd, $\left.J=10.8,5.0 \mathrm{~Hz}, 1 \mathrm{H}\right), 3.25-3.17$ (m, 1H), $1.84-1.66(\mathrm{~m}, 5 \mathrm{H}), 1.65-1.60(\mathrm{~m}, 1 \mathrm{H}), 1.55(\mathrm{~s}, 6 \mathrm{H}), 1.31-1.10(\mathrm{~m}, 3 \mathrm{H}), 1.10-0.90(\mathrm{~m}, 2 \mathrm{H}) ;{ }^{13} \mathrm{C}$ NMR (MeOD-d 4,100 MHz): $\delta 169.5,102.6$, 78.2, 74.0, 42.6, 39.9, 32.9, 32.1, 27.6, 27.6, 27.5, 25.9; HRMS $m / z 322.1254\left[\mathrm{C}_{14} \mathrm{H}_{21} \mathrm{NO}_{6}(\mathrm{M}+\mathrm{Na})^{+}\right.$requires 322.1266].

2,2-Dimethyl-5-(1-nitrohexan-2-yl)-1,3-dioxane-4,6-dione (5j). Prepared according to the general procedure. Purification of a small sample for analytical purposes by flash chromatography $\left(10 \% \mathrm{MeOH}\right.$ in EtOAc) gave $\mathbf{5 j}$ as a clear oil. $\mathrm{R}_{f}=0.13(50 \%$ EtOAc in hexane); IR (neat): 2956, 2930, 2863, 1782, 1741, 1718, 1553, 1383, 1311, $1206 \mathrm{~cm}^{-1} ;{ }^{1} \mathrm{H}$ NMR $\left(\mathrm{CDCl}_{3}, 400 \mathrm{MHz}\right): \delta 4.98(\mathrm{dd}, J=13.3,10.2 \mathrm{~Hz}, 1 \mathrm{H}), 4.57(\mathrm{dd}, J=13.4,4.4 \mathrm{~Hz}, 1 \mathrm{H}), 3.89$ (d, $2.4 \mathrm{~Hz}, 1 \mathrm{H}), 3.31-3.22(\mathrm{~m}, 1 \mathrm{H}), 1.81(\mathrm{~s}, 3 \mathrm{H}), 1.79(\mathrm{~s}, 3 \mathrm{H}), 1.64-1.53(\mathrm{~m}, 1 \mathrm{H}), 1.51-1.41(\mathrm{~m}, 1 \mathrm{H})$, $1.40-1.27$ (m, 4H), 0.94-0.87 (m, 3H); ${ }^{13} \mathrm{C} \mathrm{NMR}\left(\mathrm{CDCl}_{3}, 100 \mathrm{MHz}\right): \delta 164.0,105.5,75.8,46.9$, $36.4,29.5,29.0,28.2,26.9,22.4,13.8$; HRMS $m / z 296.1106\left[\mathrm{C}_{12} \mathrm{H}_{19} \mathrm{NO}_{6}(\mathrm{M}+\mathrm{Na})^{+}\right.$requires 296.1110].

5-(1-(Benzyloxy)-3-nitropropan-2-yl)-2,2-dimethyl-1,3-dioxane-4,6-dione (5k). Prepared according to the general procedure. Purification of a small sample for analytical purposes by flash chromatography $\left(10 \% \mathrm{MeOH}\right.$ in EtOAc) gave 5k as a yellowish oil. $\mathrm{R}_{f}=\mathrm{IR}$ (neat): 2865 , 1709, 1579, 1551, 1412, 1376, $1260 \mathrm{~cm}^{-1} ;{ }^{1} \mathrm{H}$ NMR (MeOD- $d_{4}, 400 \mathrm{MHz}$ ): NB! Dicarbonyl $\alpha-$ proton not visible. Compounds 5 b-k are completely enolized in MeOD- $d_{4} . \delta 7.35-7.21(\mathrm{~m}, 5 \mathrm{H})$, $4.93(\mathrm{dd}, J=11.3,9.2 \mathrm{~Hz}, 1 \mathrm{H}), 4.74(\mathrm{dd}, J=11.3,5.5 \mathrm{~Hz}, 1 \mathrm{H}), 4.50$ (q, $J=11.6 \mathrm{~Hz}, 2 \mathrm{H}), 3.91$ $3.76\left(\mathrm{~m}, 2 \mathrm{H}\right.$, overlapping signals), $3.55(\mathrm{dd}, J=9.1,4.8 \mathrm{~Hz}, 1 \mathrm{H}), 1.55(\mathrm{~s}, 6 \mathrm{H})$; ${ }^{13} \mathrm{C}$ NMR $\left(\mathrm{MeOD}_{4}, 100 \mathrm{MHz}\right): \delta 169.3,139.9,129.3,128.8,128.5,102.9,77.4,73.7,72.5,71.5,37.1$, 25.7; HRMS $m / z 360.1064\left[\mathrm{C}_{16} \mathrm{H}_{19} \mathrm{NO}_{7}(\mathrm{M}+\mathrm{Na})^{+}\right.$requires 360.1059].

\section{General procedure for derivatization}

The crude product $(100 \mathrm{mg})$ was loaded in a $5 \mathrm{~mL}$ flask and dissolved in dry DMF $(2.5 \mathrm{~mL})$. Distilled aniline $(0.25 \mathrm{~mL})$ was added and the mixture was heated to $100{ }^{\circ} \mathrm{C}$ for 3 hours. The mixture was partitioned between $10 \mathrm{~mL}$ EtOAc and $10 \mathrm{~mL} 1 \mathrm{M} \mathrm{HCl}$, and washed further 3 times with $1 \mathrm{M} \mathrm{HCl}\left(\mathrm{à} 10 \mathrm{~mL}\right.$ ). The organic phase was dried over $\mathrm{MgSO}_{4}$, filtered and evaporated. The residue was purified by flash chromatography (EtOAc in hexane) 


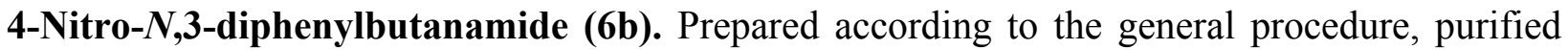
by flash chromatography (50\% EtOAc in hexane) and crystallized from EtOAc:hexane to give 6b as white crystals (10 mg): $\mathrm{R}_{f}=0.45$ (50\% EtOAc in hexane); mp 107-109 ${ }^{\circ} \mathrm{C}$; IR (neat): 3302, 3138, 3063, 3032, 1661, 1599, 1551, 1498, $1443 \mathrm{~cm}^{-1} ;{ }^{1} \mathrm{H}$ NMR $\left(\mathrm{CDCl}_{3}, 400 \mathrm{MHz}\right): \delta$ 7.40-7.23 (m, 9H), 7.15-7.06 (m, 2H), $4.85(\mathrm{dd}, J=12.6,6.4 \mathrm{~Hz}, 1 \mathrm{H}), 4.73(\mathrm{dd}, J=12.6,7.9 \mathrm{~Hz}$, 1H), $4.07(\operatorname{app~d}, J=7.1 \mathrm{~Hz}, 1 \mathrm{H}), 2.83(\mathrm{dd}, J=15.0,7.3 \mathrm{~Hz}, 1 \mathrm{H}), 2.75(\mathrm{dd}, J=15.0,7.1 \mathrm{~Hz}$, $1 \mathrm{H}) ;{ }^{13} \mathrm{C} \mathrm{NMR}\left(\mathrm{CDCl}_{3}, 100 \mathrm{MHz}\right): \delta 167.9,138.4,137.2,129.2,129.0,128.1,127.3,124.7$, 120.1 , 79.3, 40.7, 40.6; HPLC: Chiralcel OD column $(0.46 \mathrm{~cm} \times 25 \mathrm{~cm}), 25 \% i$-PrOH in hexane, $1.0 \mathrm{~mL} / \mathrm{min}, \lambda=254 \mathrm{~nm}, \mathrm{t}_{\mathrm{R}}$ (major) $17.9 \mathrm{~min}, \mathrm{t}_{\mathrm{R}}$ (minor) $23.8 \mathrm{~min}$; Anal. Calcd. for $\mathrm{C}_{16} \mathrm{H}_{16} \mathrm{~N}_{2} \mathrm{O}_{3}$ : C, 67.59; H, 5.67; N, 9.85\% Found: C, 67.50; H, 5.74; N, 9.85\%

3-(4-Methoxyphenyl)-4-nitro- $N$-phenylbutanamide (6c). Prepared according to the general procedure. Purified by flash chromatography (50\% EtOAc in hexane) and crystallized from EtOAc:hexane to give 6c as white crystals (12 mg). $\mathrm{R}_{f}=0.38$ (50\% EtOAc in hexane); mp 97-99 ${ }^{\circ} \mathrm{C}$; IR (neat): 3309, 3199, 3138, 3061, 3038, 2969, 2837, 1664, 1600, 1551, 1514, 1499, 1443, 1379, 1303, $1251 \mathrm{~cm}^{-1} ;{ }^{1} \mathrm{H} \mathrm{NMR}\left(\mathrm{CDCl}_{3}, 400 \mathrm{MHz}\right): \delta 7.37(\mathrm{~d}, J=7.6 \mathrm{~Hz}, 2 \mathrm{H}), 7.28(\mathrm{t}, J=7.9$ $\mathrm{Hz}, 2 \mathrm{H}), 7.19$ (br s, 1H), 7.16 (d, $J=8.5 \mathrm{~Hz}, 2 \mathrm{H}), 7.10$ (t, $J=7.4 \mathrm{~Hz}, 1 \mathrm{H}), 6.85$ (d, $J=8.7 \mathrm{~Hz}$, 2H), $4.80(\mathrm{dd}, J=12.5,6.5 \mathrm{~Hz}, 1 \mathrm{H}), 4.67$ (dd, $J=12.5,7.9 \mathrm{~Hz}, 1 \mathrm{H}), 4.06-3.97(\mathrm{~m}, 1 \mathrm{H}), 3.77$ (s, 3H), $2.79(\mathrm{dd}, J=15.0,7.2 \mathrm{~Hz}, 1 \mathrm{H}), 2.71(\mathrm{dd}, J=15.0,7.2 \mathrm{~Hz}, 1 \mathrm{H}),{ }^{13} \mathrm{C} \mathrm{NMR}\left(\mathrm{CDCl}_{3}, 100\right.$ MHz): $\delta 168.0,159.2,137.2,130.2,129.0,128.4,124.7,120.1,114.5,79.6,55.2,40.8,39.9$; HPLC: Chiralcel OD column $(0.46 \mathrm{~cm} \times 25 \mathrm{~cm}), 25 \% i$-PrOH in hexane, $1.0 \mathrm{~mL} / \mathrm{min}, \lambda=254$ $\mathrm{nm}, \mathrm{t}_{\mathrm{R}}$ (major) $26.1 \mathrm{~min}, \mathrm{t}_{\mathrm{R}}$ (minor) $46.7 \mathrm{~min}$; Anal. Calcd. for $\mathrm{C}_{17} \mathrm{H}_{18} \mathrm{~N}_{2} \mathrm{O}_{4}: \mathrm{C}, 64.96 ; \mathrm{H}, 5.77 ; \mathrm{N}$, 8.91\% Found: C, 64.81; H, 5.63; N, 8.86\%

3-(3-Methoxyphenyl)-4-nitro- $\boldsymbol{N}$-phenylbutanamide (6d). Prepared according to the general procedure. Purified by flash chromatography (50\% EtOAc in hexane) and crystallized from EtOAc:hexane to give $\mathbf{6 d}$ as white crystals $(16 \mathrm{mg}) . \mathrm{R}_{f}=0.39$ (50\% EtOAc in hexane); mp 101$103{ }^{\circ} \mathrm{C}$; IR (neat): 3303, 3139, 3059, 2919, 2837, 1661, 1600, 1551, 1498, 1443, 1378, $1260 \mathrm{~cm}^{-}$ ${ }^{1}$; ${ }^{1} \mathrm{H}$ NMR $\left(\mathrm{CDCl}_{3}, 400 \mathrm{MHz}\right): \delta 7.41-7.34(\mathrm{~m}, 2 \mathrm{H}), 7.32-7.23(\mathrm{~m}, 3 \mathrm{H}), 7.14-7.07(\mathrm{~m}, 2 \mathrm{H}), 6.86-$ $6.76(\mathrm{~m}, 3 \mathrm{H}), 4.84(\mathrm{dd}, J=12.6,6.4 \mathrm{~Hz}, 1 \mathrm{H}), 4.72(\mathrm{dd}, J=12.6,7.9 \mathrm{~Hz}, 1 \mathrm{H}), 4.09-4.00(\mathrm{~m}, 1 \mathrm{H})$, $3.77(\mathrm{~s}, 3 \mathrm{H}), 2.81(\mathrm{dd}, J=15.1,7.2 \mathrm{~Hz}, 1 \mathrm{H}), 2.75(\mathrm{dd}, J=15.0,7.0 \mathrm{~Hz}) ;{ }^{13} \mathrm{C} \mathrm{NMR}\left(\mathrm{CDCl}_{3}, 100\right.$ $\mathrm{MHz}): \delta 167.8,160.1,140.0,137.2,130.3,129.0,124.7,120.0,119.4,113.5,113.2,79.2,55.2$, 40.7, 40.6; HPLC: Chiralcel OD column $(0.46 \mathrm{~cm} \times 25 \mathrm{~cm}), 25 \% i-\mathrm{PrOH}$ in hexane, $1.0 \mathrm{~mL} / \mathrm{min}$, $\lambda=254 \mathrm{~nm}, \mathrm{t}_{\mathrm{R}}$ (major) $16.6 \mathrm{~min}, \mathrm{t}_{\mathrm{R}}$ (minor) $21.3 \mathrm{~min}$; Anal. Calcd. for $\mathrm{C}_{17} \mathrm{H}_{18} \mathrm{~N}_{2} \mathrm{O}_{4}: \mathrm{C}, 64.96$; $\mathrm{H}$, 5.77; N, 8.91\% Found: C, 64.80; H, 5.50; N, 8.88\%

3-(4-Bromophenyl)-4-nitro- $N$-phenylbutanamide (6e). Prepared according to the general procedure. Purified by flash chromatography (40\% EtOAc in hexane) and crystallized from EtOH: $\mathrm{H}_{2} \mathrm{O}$ to give $6 \mathrm{e}$ as white crystals $(10 \mathrm{mg}) . \mathrm{R}_{f}=0.42$ (50\% EtOAc in hexane); mp 127-130 ${ }^{\circ} \mathrm{C}$; IR (neat): 3302, 3139, 3062, 2918, 1662, 1599, 1551, 1498, 1443, $1377 \mathrm{~cm}^{-1}$; ${ }^{1} \mathrm{H}$ NMR $\left(\mathrm{CDCl}_{3}, 400 \mathrm{MHz}\right): \delta 7.47(\mathrm{~d}, J=8.4 \mathrm{~Hz}, 2 \mathrm{H}), 7.39(\mathrm{~d}, J=7.7 \mathrm{~Hz}, 2 \mathrm{H}), 7.31(\mathrm{t}, J=7.9 \mathrm{~Hz}, 2 \mathrm{H})$, $7.18-7.08(\mathrm{~m}, 4 \mathrm{H}), 4.84(\mathrm{dd}, J=12.8,6.3 \mathrm{~Hz}, 1 \mathrm{H}), 4.71(\mathrm{dd}, J=12.8,8.0 \mathrm{~Hz}, 1 \mathrm{H}), 4.11-4.01(\mathrm{~m}$, $1 \mathrm{H}), 2.82(\mathrm{dd}, J=15.3,7.3 \mathrm{~Hz}, 1 \mathrm{H}), 2.73(\mathrm{dd}, J=15.3,6.9 \mathrm{~Hz}, 1 \mathrm{H}) ;{ }^{13} \mathrm{C} \mathrm{NMR}\left(\mathrm{CDCl}_{3}, 100\right.$ 
MHz): $\delta 167.5,137.5,137.1,132.3,129.1,124.9,122.1,120.1,79.0,40.3,39.9$; HPLC: Chiralcel OD column $(0.46 \mathrm{~cm} \times 25 \mathrm{~cm}), 25 \% i-\mathrm{PrOH}$ in hexane, $1.0 \mathrm{~mL} / \mathrm{min}, \lambda=254 \mathrm{~nm}$, $\mathrm{t}_{\mathrm{R}}$ (major) $14.5 \mathrm{~min}, \mathrm{t}_{\mathrm{R}}$ (minor) $17.7 \mathrm{~min}$; Anal. Calcd. for $\mathrm{C}_{16} \mathrm{H}_{15} \mathrm{BrN}_{2} \mathrm{O}_{3}: \mathrm{C}, 52.91 ; \mathrm{H}, 4.16 ; \mathrm{N}$, 7.71\% Found: C, $52.93 ; \mathrm{H}, 3.84 ; \mathrm{N}, 7.55 \%$

3-(3-Bromophenyl)-4-nitro- $N$-phenylbutanamide (6f). Prepared according to the general procedure. Purified by flash chromatography (40\% EtOAc in hexane) and crystallized from EtOAc:hexane to give $6 \mathbf{f}$ as white crystals $(13 \mathrm{mg}) . \mathrm{R}_{f}=0.45$ (50\% EtOAc in hexane); mp 110$11{ }^{\circ} \mathrm{C}$; IR (neat): $3302,3199,3139,3061,2918,1661,1598,1551,1498,1443,1376 \mathrm{~cm}^{-1} ;{ }^{1} \mathrm{H}$ NMR ( $\left.\mathrm{CDCl}_{3}, 400 \mathrm{MHz}\right): \delta 7.45-7.36(\mathrm{~m}, 4 \mathrm{H}), 7.30(\mathrm{t}, J=7.9 \mathrm{~Hz}, 2 \mathrm{H}), 7.24-7.16(\mathrm{~m}, 3 \mathrm{H}), 7.12$ $(\mathrm{t}, J=7.3 \mathrm{~Hz}, 1 \mathrm{H}), 4.84(\mathrm{dd}, J=12.8,6.3 \mathrm{~Hz}, 1 \mathrm{H}), 4.71(\mathrm{dd}, J=12.8,8.0 \mathrm{~Hz}, 1 \mathrm{H}), 4.10-4.01(\mathrm{~m}$, $1 \mathrm{H}), 2.81(\mathrm{dd}, J=15.4,7.5 \mathrm{~Hz}, 1 \mathrm{H}), 2.73(\mathrm{dd}, J=15.4,6.9 \mathrm{~Hz}, 1 \mathrm{H}) ;{ }^{13} \mathrm{C} \mathrm{NMR}\left(\mathrm{CDCl}_{3}, 100\right.$ MHz): $\delta 167.5,140.8,137.1,131.3,130.7,130.4,129.1,126.2,124.9,123.1,120.1,78.9,40.2$, 40.0; HPLC: Chiralcel OD column $(0.46 \mathrm{~cm} \times 25 \mathrm{~cm}), 25 \% i-\mathrm{PrOH}$ in hexane, $1.0 \mathrm{~mL} / \mathrm{min}, \lambda=$ $254 \mathrm{~nm}, \mathrm{t}_{\mathrm{R}}$ (major) $16.3 \mathrm{~min}, \mathrm{t}_{\mathrm{R}}$ (minor) $18.8 \mathrm{~min}$; Anal. Calcd. for $\mathrm{C}_{16} \mathrm{H}_{15} \mathrm{BrN}_{2} \mathrm{O}_{3}: \mathrm{C}, 52.91 ; \mathrm{H}$, 4.16; N, 7.71\% Found: C, 52.99; H, 3.82; N, 7.71\%

3-(Furan-2-yl)-4-nitro- $N$-phenylbutanamide (6g). Prepared according to the general procedure. Purified by flash chromatography ( $40 \%$ EtOAc in hexane) and crystallized from EtOAc:hexane to give $\mathbf{6 g}$ as white crystals $(10 \mathrm{mg}) . \mathrm{R}_{f}=0.48$ (50\% EtOAc in hexane); mp 111$124{ }^{\circ} \mathrm{C}$; IR (neat): $3304,3141,2918,1662,1600,1552,1499,1444,1376 \mathrm{~cm}^{-1} ;{ }^{1} \mathrm{H}$ NMR $\left(\mathrm{CDCl}_{3}, 400 \mathrm{MHz}\right): \delta 7.43(\mathrm{~d}, J=8.1 \mathrm{~Hz}, 2 \mathrm{H}), 7.37(\mathrm{~d}, J=1.1 \mathrm{~Hz}, 1 \mathrm{H}), 7.31(\mathrm{t}, J=7.9 \mathrm{~Hz}, 2 \mathrm{H})$, 7.22 (br. s, $1 \mathrm{H}), 7.12$ (t, $J=7.3 \mathrm{~Hz}, 1 \mathrm{H}), 6.31$ (dd, $J=3.1,1.8 \mathrm{~Hz}, 1 \mathrm{H}), 6.21$ (d, $J=3.3 \mathrm{~Hz}, 1 \mathrm{H})$, $4.84(\mathrm{dd}, J=12.6,5.9 \mathrm{~Hz}, 1 \mathrm{H}), 4.76(\mathrm{dd}, J=12.6,7.1 \mathrm{~Hz}, 1 \mathrm{H}), 4.23-4.15(\mathrm{~m}, 1 \mathrm{H}), 2.87(\mathrm{dd}, J=$ 15.0, 6.6 Hz, $1 \mathrm{H}), 2.82(\mathrm{dd}, J=15.1,7.4 \mathrm{~Hz}, 1 \mathrm{H}),{ }^{13} \mathrm{C} \mathrm{NMR}\left(\mathrm{CDCl}_{3}, 100 \mathrm{MHz}\right): \delta 167.6,151.3$, 142.5, 137.2, 129.1, 124.8, 120.1, 110.6, 107.5, 77.1, 38.1, 34.5; HPLC: Chiralcel OD column $(0.46 \mathrm{~cm} \times 25 \mathrm{~cm}), 25 \% i$-PrOH in hexane, $1.0 \mathrm{~mL} / \mathrm{min}, \lambda=254 \mathrm{~nm}, \mathrm{t}_{\mathrm{R}}$ (major) $12.0 \mathrm{~min}$, $\mathrm{t}_{\mathrm{R}}$ (minor) $15.1 \mathrm{~min}$; Anal. Calcd. for $\mathrm{C}_{14} \mathrm{H}_{14} \mathrm{~N}_{2} \mathrm{O}_{4}$ : C, 61.31; H, 5.14; N, 10.21\% Found: $\mathrm{C}, 61.26$; $\mathrm{H}, 4.98 ; \mathrm{N}, 10.16 \%$

3-(Furan-3-yl)-4-nitro- $N$-phenylbutanamide (6h). Prepared according to the general procedure. Purified by flash chromatography (40\% EtOAc in hexane) and crystallized from EtOAc:hexane to give $\mathbf{6 h}$ as white crystals $(10 \mathrm{mg}) . \mathrm{R}_{f}=0.42$ (50\% EtOAc in hexane); mp 101$107{ }^{\circ} \mathrm{C}$; IR (neat): 3302, 3136, 2918, 1664, 1599, 1551, 1499, 1443, $1377 \mathrm{~cm}^{-1} ;{ }^{1} \mathrm{H}$ NMR $\left(\mathrm{CDCl}_{3}, 400 \mathrm{MHz}\right): \delta 7.44(\mathrm{~d}, J=7.7 \mathrm{~Hz}, 2 \mathrm{H}), 7.40(\mathrm{t}, J=1.6 \mathrm{~Hz}, 1 \mathrm{H}), 7.37$ (br s, $\left.1 \mathrm{H}\right), 7.32$ (app t, $J=7.9 \mathrm{~Hz}, 2 \mathrm{H}), 7.19$ (br s, 1H), 7.12 (app t, $J=7.4 \mathrm{~Hz}, 1 \mathrm{H}), 6.34$ (br s., $1 \mathrm{H}), 4.80$ (dd, $J=$ 12.5, $6.0 \mathrm{~Hz}, 1 \mathrm{H}), 4.67(\mathrm{dd}, J=12.5,7.3 \mathrm{~Hz}, 1 \mathrm{H}), 4.02(\operatorname{app~d}, J=6.8 \mathrm{~Hz}, 1 \mathrm{H}), 2.79(\mathrm{dd}, J=$ 15.2, 7.3 Hz, $1 \mathrm{H}), 2.72(\mathrm{dd}, J=15.1,6.7 \mathrm{~Hz}, 1 \mathrm{H}) ;{ }^{13} \mathrm{C} \mathrm{NMR}\left(\mathrm{CDCl}_{3}, 100 \mathrm{MHz}\right): \delta 167.8,143.9$, 139.8, 137.2, 129.1, 124.8, 122.7, 120.0, 108.8, 78.8, 40.1, 31.8; HPLC: Chiralcel OD column $(0.46 \mathrm{~cm} \times 25 \mathrm{~cm}), 25 \% i$-PrOH in hexane, $1.0 \mathrm{~mL} / \mathrm{min}, \lambda=254 \mathrm{~nm}, \mathrm{t}_{\mathrm{R}}$ (major) $13.0 \mathrm{~min}$, $\mathrm{t}_{\mathrm{R}}$ (minor) 16.0 min; Anal. Calcd. for $\mathrm{C}_{14} \mathrm{H}_{14} \mathrm{~N}_{2} \mathrm{O}_{4}$ : C, 61.31; H, 5.14; N, 10.21\% Found: $\mathrm{C}, 61.07$; $\mathrm{H}, 5.10 ; \mathrm{N}, 10.18 \%$ 
3-Cyclohexyl-4-nitro- $N$-phenylbutanamide (6i). Prepared according to the general procedure. Purified by CombiFlash ( 0 to $15 \%$ EtOAc in hexane) to give $6 \mathbf{i}$ as a yellow oil in quite poor yield. $\mathrm{R}_{f}=0.61$ (50\% EtOAc in hexane); IR (neat): 3302, 3139, 3061, 2958, 2931, 2861, 1661, 1600, 1548, 1499, 1443, $1380 \mathrm{~cm}^{-1}$; ${ }^{1} \mathrm{H} \mathrm{NMR}\left(\mathrm{CDCl}_{3}, 400 \mathrm{MHz}\right): \delta 7.50(\mathrm{~d}, J=7.7 \mathrm{~Hz}, 2 \mathrm{H})$, 7.33 (t, $J=7.9 \mathrm{~Hz}, 2 \mathrm{H}), 7.28-7.23$ (br. s, $1 \mathrm{H}), 4.62$ (dd, $J=12.4,6.3 \mathrm{~Hz}, 1 \mathrm{H}), 4.53$ (dd, $J=12.3$, $5.1 \mathrm{~Hz}, 1 \mathrm{H}), 2.65-2.56(\mathrm{~m}, 2 \mathrm{H}), 2.43(\mathrm{dd}, J=16.5,9.5 \mathrm{~Hz}, 1 \mathrm{H}), 1.85-1.73(\mathrm{~m}, 4 \mathrm{H}), 1.72-1.65(\mathrm{~m}$, $1 \mathrm{H}), 1.55-1.46(\mathrm{~m}, 1 \mathrm{H}), 1.32-1.19(\mathrm{~m}, 2 \mathrm{H}), 1.19-1.10(\mathrm{~m}, 1 \mathrm{H}), 1.09-0.96(\mathrm{~m}, 2 \mathrm{H}) ;{ }^{13} \mathrm{C}$ NMR $\left(\mathrm{CDCl}_{3}, 100 \mathrm{MHz}\right): \delta 169.2,137.5,129.1,124.6,119.9,76.8,40.0,38.9,36.5,30.3,29.9,26.2$, 26.2; HPLC: Chiralcel OD column $(0.46 \mathrm{~cm} \times 25 \mathrm{~cm}), 10 \% i$-PrOH in hexane, $0.7 \mathrm{~mL} / \mathrm{min}, \lambda=$ $254 \mathrm{~nm}, \mathrm{t}_{\mathrm{R}}$ (major) $22.9 \mathrm{~min}, \mathrm{t}_{\mathrm{R}}$ (minor) $26.8 \mathrm{~min}$; HRMS m/z $313.1540\left[\mathrm{C}_{16} \mathrm{H}_{22} \mathrm{~N}_{2} \mathrm{O}_{3}(\mathrm{M}+\mathrm{Na})^{+}\right.$ requires 313.1528$]$.

3-(Nitromethyl)- $\boldsymbol{N}$-phenylheptanamide (6j). Prepared according to the general procedure. Purified by CombiFlash ( 0 to $15 \%$ EtOAc in hexane) and crystallized from EtOAc:hexane to give $\mathbf{6 j}$ as white crystals $(9 \mathrm{mg}) . \mathrm{R}_{f}=0.59$ (50\% EtOAc in hexane); mp 75-76 ${ }^{\circ} \mathrm{C}$; IR (neat): 3307, 3200, 3139, 3061, 2926, 2854, 1711, 1661, 1600, 1549, 1499, 1443, $1379 \mathrm{~cm}^{-1}$; ${ }^{1} \mathrm{H}$ NMR $\left(\mathrm{CDCl}_{3}, 400 \mathrm{MHz}\right): \delta 7.51(\mathrm{~d}, J=7.7 \mathrm{~Hz}, 2 \mathrm{H}), 7.36-7.28(\mathrm{~m}, 3 \mathrm{H}), 7.13(\mathrm{t}, J=7.4 \mathrm{~Hz}, 1 \mathrm{H}), 4.60$ $(\mathrm{dd}, J=12.1,5.9 \mathrm{~Hz}, 1 \mathrm{H}), 4.53(\mathrm{dd}, J=12.0,5.0 \mathrm{~Hz}, 1 \mathrm{H}), 2.74-2.63(\mathrm{~m}, 1 \mathrm{H}), 2.52(\mathrm{dd}, J=15.2$, $5.9 \mathrm{~Hz}, 1 \mathrm{H}), 2.48(\mathrm{dd}, J=15.2,7.7 \mathrm{~Hz}, 1 \mathrm{H}), 1.53-1.45(\mathrm{~m}, 2 \mathrm{H}), 1.42-1.29(\mathrm{~m}, 4 \mathrm{H}), 0.91(\mathrm{t}, J=$ $7.0 \mathrm{~Hz}, 3 \mathrm{H}) ;{ }^{13} \mathrm{C} \mathrm{NMR}\left(\mathrm{CDCl}_{3}, 100 \mathrm{MHz}\right)$ : partial, anilide quaternary $C$ not seen, $\delta 168.8$, 129.1, 124.6, 119.9, 78.4, 39.1, 34.9, 31.1, 28.8, 22.5, 13.9; HPLC: Chiralcel OD column (0.46 $\mathrm{cm} \times 25 \mathrm{~cm}$ ), $15 \% i-\mathrm{PrOH}$ in hexane, $1.0 \mathrm{~mL} / \mathrm{min}, \lambda=254 \mathrm{~nm}, \mathrm{t}_{\mathrm{R}}$ (major) $18.6 \mathrm{~min}, \mathrm{t}_{\mathrm{R}}$ (minor) 23.0 min; Anal. Calcd. for $\mathrm{C}_{14} \mathrm{H}_{20} \mathrm{~N}_{2} \mathrm{O}_{3}$ : C, 63.62; H, 7.63; N, 10.60\% Found: C, 63.59; H, 8.06; $\mathrm{N}, 10.60 \%$

4-(Benzyloxy)-3-(nitromethyl)- $N$-phenylbutanamide (6k). Prepared according to the general procedure. Purified by flash chromatography (40\% EtOAc in hexane) and crystallized from EtOH: $\mathrm{H}_{2} \mathrm{O}$ to give 6k as white crystals $(17 \mathrm{mg}) . \mathrm{R}_{f}=0.51$ (50\% EtOAc in hexane); mp 82-85 ${ }^{\circ} \mathrm{C}$; IR (neat): 3310, 3138, 3062, 3031, 2864, 1663, 1600, 1550, 1498, 1443, $1380 \mathrm{~cm}^{-1}$; ${ }^{1} \mathrm{H}$ NMR $\left(\mathrm{CDCl}_{3}, 400 \mathrm{MHz}\right): \delta 7.43(\mathrm{~d}, J=7.7 \mathrm{~Hz}, 2 \mathrm{H}), 7.37-7.27(\mathrm{~m}, 8 \mathrm{H}), 7.12(\mathrm{t}, J=7.4 \mathrm{~Hz}, 1 \mathrm{H}), 4.61$ (d, $J=6.4 \mathrm{~Hz}, 2 \mathrm{H}), 4.51$ (dd, $A B$ system, $J=13.5,11.9 \mathrm{~Hz}, 2 \mathrm{H}), 3.60$ (app d, $J=5.3 \mathrm{~Hz}, 2 \mathrm{H})$, $3.10-3.00(\mathrm{~m}, 1 \mathrm{H}), 2.57(\mathrm{dd}, J=15.2,6.8 \mathrm{~Hz}, 1 \mathrm{H}), 2.51(\mathrm{dd}, J=15.2,6.8 \mathrm{~Hz}, 1 \mathrm{H}) ;{ }^{13} \mathrm{C}$ NMR $\left(\mathrm{CDCl}_{3}, 100 \mathrm{MHz}\right): \delta 168.3,137.5,137.4,129.0,128.5,128.0,127.8,124.6,119.9,76.3,73.5$, 69.4, 36.4, 35.3; HPLC: Chiralpak AS column $(0.46 \mathrm{~cm} \times 25 \mathrm{~cm}), 10 \% i$-PrOH in hexane, 1.0 $\mathrm{mL} / \mathrm{min}, \lambda=254 \mathrm{~nm}, \mathrm{t}_{\mathrm{R}}$ (major) $75.7 \mathrm{~min}, \mathrm{t}_{\mathrm{R}}$ (minor) $86.8 \mathrm{~min}$; Anal. Calcd. for $\mathrm{C}_{18} \mathrm{H}_{20} \mathrm{~N}_{2} \mathrm{O}_{4}$ : $\mathrm{C}$, 65.84; H, 6.14; N, 8.53\% Found: C, 65.79; H, 6.35; N, 8.53\%

\section{1-Cyclohexyl-3-((R)-(6-methoxyquinolin-4-yl)((2R,4S,5R)-5-vinylquinuclidin-2-yl)methyl)-}

thiourea (11). To a solution of $14(180 \mathrm{mg}, 0.56 \mathrm{mmol}, 100 \mathrm{~mol} \%)$ in dry THF (2 mL) was added freshly distilled cyclohexyl isothiocyanate $(90 \mu \mathrm{L}, 0.63 \mathrm{mmol}, 110 \mathrm{~mol} \%)$. Mixture was stirred under Ar overnight. Solvents were evaporated, and purification by flash chromatography ( $8 \%$ to $10 \% \mathrm{MeOH}$ in $\mathrm{CH}_{2} \mathrm{Cl}_{2}$ ) gave 11 as white foam (124 mg, 48\%). $\mathrm{R}_{f}=0.30(10 \% \mathrm{MeOH}$ in 
$\left.\mathrm{CH}_{2} \mathrm{Cl}_{2}\right) ;[\alpha]^{20}{ }_{\mathrm{D}}=+218.5\left(c=1.0, \mathrm{CHCl}_{3}\right)$; IR (neat): 3247 (broad), 3067, 2999, 2933, 2856, 2669, 2212, 1622, 1589, 1542, 1509, 1474, 1452, 1433, 1364, 1337, 1321, $1227 \mathrm{~cm}^{-1}$; ${ }^{1} \mathrm{H} \mathrm{NMR}$ $\left(\mathrm{CDCl}_{3}, 400 \mathrm{MHz}\right): \delta 8.75(\mathrm{~d}, J=4.6 \mathrm{~Hz}, 1 \mathrm{H}), 8.03(\mathrm{~d}, J=9.1 \mathrm{~Hz}, 1 \mathrm{H}), 7.63(\mathrm{~d}, J=1.8 \mathrm{~Hz}, 1 \mathrm{H})$, 7.50-7.45 (br s, 1H), $7.45(\mathrm{~d}, J=4.6 \mathrm{~Hz}, 1 \mathrm{H}), 7.41(\mathrm{dd}, J=9.2,2.7 \mathrm{~Hz}, 1 \mathrm{H}), 5.89$ (ddd, $J=17.2$, $10.7,6.3 \mathrm{~Hz}), 5.24-5.15$ (m, 2H), 3.99 (s, 3H), 3.34-3.20 (m, 1H), 3.20-2.90 (m, 5H), 2.45-2.34 $(\mathrm{m}, 1 \mathrm{H}), 1.99-1.87(\mathrm{~m}, 1 \mathrm{H}), 1.83-1.70(\mathrm{~m}, 2 \mathrm{H}), 1.70-1.46(\mathrm{~m}, 4 \mathrm{H}), 1.46-1.37(\mathrm{~m}, 1 \mathrm{H}), 1.37-1.16$ $(\mathrm{m}, 4 \mathrm{H}), 1.16-0.97(\mathrm{~m}, 3 \mathrm{H}), 0.97-0.79(\mathrm{~m}, 1 \mathrm{H}) ;{ }^{13} \mathrm{C} \mathrm{NMR}\left(\mathrm{CDCl}_{3}, 100 \mathrm{MHz}\right): \delta 180.9,158.1$, 147.6, 144.8, 139.3, 131.8, 127.6, 122.4, 120.1, 115.4, 101.3, 61.1, 55.7, 53.3, 48.8, 46.8, 38.5, $32.5,32.3,27.1,25.8,25.3,24.8,24.3$; HRMS $m / z 487.2510\left[\mathrm{C}_{27} \mathrm{H}_{36} \mathrm{~N}_{4} \mathrm{OS}(\mathrm{M}+\mathrm{H})^{+}\right.$requires 487.2508].

Ethyl $(R)-(6-m e t h o x y q u i n o l i n-4-y l)((2 R, 4 S, 5 R)-5$-vinylquinuclidin-2-yl)methyl carbamate (15). To a solution of 14 (715 mg, $2.2 \mathrm{mmol}, 100 \mathrm{~mol} \%)$ in dry THF (10 mL) was added $\mathrm{Et}_{3} \mathrm{~N}$ $(330 \mu \mathrm{L}, 2.4 \mathrm{mmol}, 110 \mathrm{~mol} \%)$, followed by slow addition of ethyl chloroformate $(230 \mu \mathrm{L}, 2.4$ mmol, $110 \mathrm{~mol} \%$ ). The mixture was stirred at room temperature under Ar for 2 hours. The solvent was partly evaporated, and the mixture was partitioned between $\mathrm{H}_{2} \mathrm{O}(30 \mathrm{~mL})$ and $\mathrm{Et}_{2} \mathrm{O}$ $(30 \mathrm{~mL})$. The aqueous phase was washed with $\mathrm{Et}_{2} \mathrm{O}(3 \times 20 \mathrm{~mL})$. The organic phases were combined and washed with brine, then dried over $\mathrm{MgSO}_{4}$, filtered and evaporated. Purification by flash chromatography gave 16 as a white foam $(463 \mathrm{mg}, 53 \%) . \mathrm{R}_{f}=0.23(10 \% \mathrm{MeOH}$ in $\left.\mathrm{CH}_{2} \mathrm{Cl}_{2}\right) ;[\alpha]_{\mathrm{D}}^{20}=+176.6\left(c=1.0, \mathrm{CHCl}_{3}\right)$; IR (neat): 3185, 3075, 2936, 2870, 1709, 1622, 1590, $1508,1474,1433,1365,1298,1252,1227 \mathrm{~cm}^{-1} ;{ }^{1} \mathrm{H} \mathrm{NMR}\left(\mathrm{C}_{2} \mathrm{D}_{2} \mathrm{Cl}_{4}, 400 \mathrm{MHz}, 85^{\circ} \mathrm{C}\right): \delta 8.74(\mathrm{~d}$, $J=4.6 \mathrm{~Hz}, 1 \mathrm{H}), 8.06(\mathrm{~d}, J=9.3 \mathrm{~Hz}, 1 \mathrm{H}), 7.62(\mathrm{~d}, J=2.7 \mathrm{~Hz}, 1 \mathrm{H}), 7.41(\mathrm{dd}, J=11.9,2.7 \mathrm{~Hz}$, $1 \mathrm{H}), 7.40$ (br s, 1H), 6.09 (br s, 1H), $6.01-5.91(\mathrm{~m}, 1 \mathrm{H}), 5.18$ (d, $J=1.5 \mathrm{~Hz}, 1 \mathrm{H}), 5.11$ (dt, $J=$ $6.3,1.5 \mathrm{~Hz}, 1 \mathrm{H}), 5.10(\mathrm{dd}, J=10.5,3.0 \mathrm{~Hz}, 1 \mathrm{H}), 4.00$ (s, 3H), 3.99 (q, $J=7.1 \mathrm{~Hz}, 2 \mathrm{H}), 3.09-2.90$ (m, 5H), 2.39-2.31 (m, 1H), 1.73-1.68 (m, 1H), 1.65-1.48 (m, 2H), 1.39-1.31 (m, 1H), $1.10(\mathrm{t}, J$ $=7.1 \mathrm{~Hz}, 3 \mathrm{H}), 1.07-.098(\mathrm{~m}, 1 \mathrm{H}) ;{ }^{13} \mathrm{C} \mathrm{NMR}\left(\mathrm{CDCl}_{3}, 100 \mathrm{MHz}, 60^{\circ} \mathrm{C}\right): 157.9,156.5,147.6$, $145.8,145.0,140.5,131.9,128.4,121.7,119.5,114.7,101.7,60.8,60.4,55.5,49.4,47.3,39.3$, 27.6, 26.8, 25.5, 14.3; HRMS $m / z 396.2293\left[\mathrm{C}_{23} \mathrm{H}_{30} \mathrm{~N}_{3} \mathrm{O}_{3}(\mathrm{M}+\mathrm{H})^{+}\right.$requires 396.2287].

9- $\mathrm{N}$-Methylamino-(9-deoxy)-epi-quinidine (16). Lithium aluminum hydride (100 mg, 2.6 mmol, $260 \mathrm{~mol} \%$ ) was suspended in dry THF (4 mL) at $0{ }^{\circ} \mathrm{C}$ under Ar. Compound 15 (390 mg, $1.0 \mathrm{mmol}, 100 \mathrm{~mol} \%)$ was added as a solution in dry THF $(8 \mathrm{~mL})$. The reaction was stirred at $0^{\circ} \mathrm{C}$ for 6 hours, then allowed to warm to room temperature and stirred overnight. $\mathrm{LiAlH}_{4}$ added as THF suspension ( $1 \mathrm{mmol}, 100 \mathrm{~mol} \%)$ to drive the reaction to completion. The reaction was quenched by adding $\mathrm{H}_{2} \mathrm{O}(1.4 \mathrm{~mL}), 10 \mathrm{M} \mathrm{NaOH}(0.15 \mathrm{~mL})$ and $\mathrm{H}_{2} \mathrm{O} 0.6 \mathrm{~mL}$ sequentially to give a yellow mixture. The organic phase was dried over $\mathrm{MgSO}_{4}$, filtered and evaporated to give a yellow foam. Purification by flash chromatography $\left(9 \% \mathrm{MeOH}\right.$ in $\left.\mathrm{CH}_{2} \mathrm{Cl}_{2}, 1 \% \mathrm{NH}_{4} \mathrm{OH}\right)$ gave 16 as a yellow oil $(170 \mathrm{mg}, 51 \%) . \mathrm{R}_{f}=0.31\left(10 \% \mathrm{MeOH}\right.$ in $\left.\mathrm{CH}_{2} \mathrm{Cl}_{2}\right) ;[\alpha]_{\mathrm{D}}^{20}=+56.6(c=1.0$, $\mathrm{CHCl}_{3}$ ); IR (neat): 3317, 3075, 2937, 2870, 2787, 1666, 1621, 1588, 1508, 1473, 1454, 1432, 1357, 1257, 1240, $1226 \mathrm{~cm}^{-1} ;{ }^{1} \mathrm{H} \mathrm{NMR}\left(\mathrm{CDCl}_{3}, 400 \mathrm{MHz}\right.$, partial spectra, probably due to heavy rotamerism): $\delta 8.77(\mathrm{br} \mathrm{s}, 1 \mathrm{H}), 8.03(\mathrm{~d}, J=9.5 \mathrm{~Hz}, 1 \mathrm{H}), 7.77-7.41(\mathrm{~m}, 2 \mathrm{H}), 7.38(\mathrm{dd}, J=$ 9.2, $2.7 \mathrm{~Hz}, 1 \mathrm{H}), 5.92$ (ddd, $J=17.5,10.1,6.6 \mathrm{~Hz}, 1 \mathrm{H}), 5.12-5.05$ (m, 2H), 4.36 (br s, 1H), 3.97 
(s, 3H), 3.08-2.80 (m, 5H), 2.32-2.23 (m, 1H), $2.20(\mathrm{~s}, 3 \mathrm{H}), 1.62-1.46(\mathrm{~m}, 3 \mathrm{H}), 1.24-1.15(\mathrm{~m}$, $1 \mathrm{H})$, 0.89-0.73 (m, $1 \mathrm{H}) ;{ }^{13} \mathrm{C} \mathrm{NMR}\left(\mathrm{CDCl}_{3}, 100 \mathrm{MHz}, 55^{\circ} \mathrm{C}\right.$, partial spectra, probably due to heavy rotamerism): $\delta 157.5,147.8$ (broad, possibly 2 signals), 144.9, 140.9, 131.8, 129.6, 121.3, 114.4, 102.1, 55.5, 49.6, 47.8, 39.7, 34.3, 27.7, 26.8, 25.0; HRMS m/z 338.2227 $\left[\mathrm{C}_{21} \mathrm{H}_{28} \mathrm{~N}_{3} \mathrm{O}\right.$ $(\mathrm{M}+\mathrm{H})^{+}$requires 338.2232$]$.

$\mathrm{N}$-Methyl-3,5-bis(trifluoromethyl)aniline (19). 3,5-Bis(trifluoromethyl)aniline (1.0 mL, 6.4 mmol, $100 \mathrm{~mol} \%)$ was dissolved in $\mathrm{CH}_{2} \mathrm{Cl}_{2}(14 \mathrm{~mL})$ and cooled to $0{ }^{\circ} \mathrm{C}$. Trifluoroacetic anhydride $(2.7 \mathrm{~mL}, 19 \mathrm{mmol}, 300 \mathrm{~mol} \%)$ was added, and the mixture was stirred at $0{ }^{\circ} \mathrm{C}$ for 20 minutes. The solvents were evaporated, and the residue was dissolved in acetone $(15 \mathrm{~mL})$. Anhydrous $\mathrm{K}_{2} \mathrm{CO}_{3}(1.77 \mathrm{~g}, 12.8 \mathrm{mmol}, 200 \mathrm{~mol} \%)$ and iodomethane $(1.2 \mathrm{~mL}, 19 \mathrm{mmol}, 300$ mol\%) were added, and the mixture was heated to mild reflux for 2 hours. The mixture was filtered and evaporated, the residue was dissolved in $\mathrm{H}_{2} \mathrm{O}: \mathrm{MeOH}(5 \mathrm{~mL}: 25 \mathrm{~mL})$, and anhydrous $\mathrm{K}_{2} \mathrm{CO}_{3}(880 \mathrm{mg}, 6.4 \mathrm{mmol}, 100 \mathrm{~mol} \%)$ was added. The mixture was stirred at room temperature for one hour. The solvents were partly evaporated, and the residue partitioned between $\mathrm{H}_{2} \mathrm{O}$ ( 25 $\mathrm{mL})$ and $\mathrm{CH}_{2} \mathrm{Cl}_{2}(30 \mathrm{~mL})$. The aqueous phase was extracted with $\mathrm{CH}_{2} \mathrm{Cl}_{2}(30 \mathrm{~mL})$. The combined organic phases were dried over $\mathrm{MgSO}_{4}$, filtered and evaporated to give 19 as a yellowish oil (1.41 g, 90\%). The product was practically pure with some solvent residues present. No further purification was done since the compound was somewhat volatile at reduced pressures and could be lost in rigorous drying. $\mathrm{R}_{f}=0.23$ (5\% EtOAc in hexane); IR (neat): 3465 , 2927, 1623, 1523, 1485, 1385, 1273, 1168, 1116, 1100, $1072 \mathrm{~cm}^{-1} ;{ }^{1} \mathrm{H} \mathrm{NMR}\left(\mathrm{CDCl}_{3}, 400 \mathrm{MHz}\right)$ : $\delta 7.15(\mathrm{~s}, 1 \mathrm{H}), 6.92(\mathrm{~s}, 2 \mathrm{H}), 4.16(\mathrm{br} \mathrm{s}, 1 \mathrm{H}), 2.91(\mathrm{~s}, 3 \mathrm{H}) ;{ }^{13} \mathrm{C} \mathrm{NMR}\left(\mathrm{CDCl}_{3}, 100 \mathrm{MHz}\right): \delta 150.1$, $132.8\left(\mathrm{q},{ }^{2} J_{\mathrm{CF}}=33.0 \mathrm{~Hz}\right), 124.0\left(\mathrm{q},{ }^{1} J_{\mathrm{CF}}=272.0 \mathrm{~Hz}\right), 111.8,110.4,30.7$; HRMS $\mathrm{m} / z 244.0557$ $\left[\mathrm{C}_{9} \mathrm{H}_{7} \mathrm{~F}_{6} \mathrm{~N}(\mathrm{M}+\mathrm{H})^{+}\right.$requires 244.0561].

\section{3-(3,5-Bis(trifluoromethyl)phenyl)-1-((R)-(6-methoxyquinolin-4-yl)((2R,4S,5R)-5-vinyl-}

quinuclidin-2-yl)methyl)-1-methylthiourea (12). To a solution of $\mathbf{1 6}$ (140 mg, $0.42 \mathrm{mmol}, 100$ mol\%) in dry THF $(3 \mathrm{~mL})$ was added 3,5-bis(trifluoromethyl)phenyl isothiocyanate ( $90 \mu \mathrm{L}, 0.49$ mmol, $110 \mathrm{~mol} \%$ ). The mixture was stirred overnight at room temperature under Ar. The solvents were evaporated and the residue purified by flash chromatography $(5 \%$ to $10 \% \mathrm{MeOH}$ in $\left.\mathrm{CH}_{2} \mathrm{Cl}_{2}\right)$ to give 12 as a whitish foam $(181 \mathrm{mg}, 71 \%) . \mathrm{R}_{f}=0.39\left(10 \% \mathrm{MeOH}\right.$ in $\left.\mathrm{CH}_{2} \mathrm{Cl}_{2}\right)$; $[\alpha]^{20}{ }_{\mathrm{D}}=-3.8\left(c=1.0, \mathrm{CHCl}_{3}\right)$; IR (neat): 3237 (broad), 3070, 2938, 2872, 1622, 1510, 1474, $1370,1311,1278,1242,1175,1134 \mathrm{~cm}^{-1} ;{ }^{1} \mathrm{H}$ NMR (MeOD-d $\left.4,400 \mathrm{MHz}\right): \delta 8.72(\mathrm{~d}, 1 \mathrm{H}, J=4.8$ $\mathrm{Hz}), 8.53(\mathrm{~d}, 1 \mathrm{H}, J=1.8 \mathrm{~Hz}), 7.98(\mathrm{~s}, 2 \mathrm{H}), 7.93(\mathrm{~d}, 1 \mathrm{H}, J=9.3 \mathrm{~Hz}), 7.74(\mathrm{~d}, 1 \mathrm{H}, J=4.8 \mathrm{~Hz})$, $7.67(\mathrm{~s}, 1 \mathrm{H}), 7.41(\mathrm{dd}, 1 \mathrm{H}, J=9.1,2.7 \mathrm{~Hz}), 7.36(\mathrm{~d}, 1 \mathrm{H}, J=11.0 \mathrm{~Hz}$ ), 5.84 (ddd, $1 \mathrm{H}, J=17.2$, 10.7, $6.4 \mathrm{~Hz}), 5.22(\mathrm{dt}, 1 \mathrm{H}, J=17.3,1.6 \mathrm{~Hz}), 5.03(\mathrm{dt}, 1 \mathrm{H}, J=10.6,1.5 \mathrm{~Hz}), 4.09-4.00(\mathrm{~m}, 1 \mathrm{H})$, 4.00-3.90 (m, 1H), $3.98(\mathrm{~s}, 3 \mathrm{H}), 3.19-3.11(\mathrm{~m}, 1 \mathrm{H}), 3.05(\mathrm{~s}, 3 \mathrm{H}), 3.05-2.91(\mathrm{~m}, 2 \mathrm{H}), 2.36(\mathrm{q}, 1 \mathrm{H}$, $J=7.8 \mathrm{~Hz}), 1.89-1.79(\mathrm{~m}, 1 \mathrm{H}), 1.77-1.66(\mathrm{~m}, 2 \mathrm{H}), 1.59-1.49(\mathrm{~m}, 1 \mathrm{H}), 1.10-1.01(\mathrm{~m}, 1 \mathrm{H}) ;{ }^{13} \mathrm{C}$ NMR (MeOD-d $4,100 \mathrm{MHz}$ ): $\delta 184.4,160.2,147.7,145.7,144.4,143.4,141.3,132.2\left(\mathrm{q},{ }^{2} J_{\mathrm{CF}}=\right.$ $33.3 \mathrm{~Hz}), 131.3,131.1,127.2,124.8\left(\mathrm{q},{ }^{1} J_{\mathrm{CF}}=271 \mathrm{~Hz}\right), 124.3,123.0,118.7,115.2,105.7,61.0$, 
57.7, 56.4, 54.8, 50.8, 50.0, 40.3, 32.8, 28.9, 27.6, 27.2. HRMS $m / z 609.2133\left[\mathrm{C}_{30} \mathrm{H}_{31} \mathrm{~F}_{6} \mathrm{~N}_{4} \mathrm{OS}\right.$ $(\mathrm{M}+\mathrm{H})^{+}$requires 609.2123$]$.

\section{1-(3,5-Bis(trifluoromethyl)phenyl)-3-((R)-(6-methoxyquinolin-4-yl) $((2 R, 4 S, 5 R)-5$-vinyl-} quinuclidin-2-yl)methyl)-1-methylthiourea (13). Compound 18 (130 mg, $0.5 \mathrm{mmol}, 100$ mol\%) was dissolved in dry THF $(2 \mathrm{~mL})$ under $\mathrm{Ar}$ and cooled to $-78{ }^{\circ} \mathrm{C} . n$-BuLi $(2.2 \mathrm{M}, 230 \mu \mathrm{L}$, $0.5 \mathrm{mmol}, 100 \mathrm{~mol} \%$ ) was added and the resulting yellow mixture was stirred for 15 minutes. Isothiocyanate 17 (180 mg, $0.5 \mathrm{mmol}, 100 \mathrm{~mol} \%$ ) dissolved in DMF (3 mL) was added, and the mixture was stirred at $-78{ }^{\circ} \mathrm{C}$ for 40 minutes, then allowed to warm to room temperature and stirred for further one hour. The reaction was quenched by adding sat. $\mathrm{NH}_{4} \mathrm{Cl}(1.0 \mathrm{~mL})$, and the mixture was partitioned between $\mathrm{H}_{2} \mathrm{O}(15 \mathrm{~mL})$ and EtOAc $(15 \mathrm{~mL})$. The organic layer was washed with $\mathrm{H}_{2} \mathrm{O}(3 \times 10 \mathrm{~mL})$, dried over $\mathrm{MgSO}_{4}$, filtered and evaporated. The residue was purified by flash chromatography $\left(3 \%\right.$ to $10 \% \mathrm{MeOH}$ in $\left.\mathrm{CH}_{2} \mathrm{Cl}_{2}\right)$ to give 13 as an amorphous solid (158 mg, 52\%). Another product was also isolated $(50 \mathrm{mg})$ which had identical HRMS spectra and highly similar NMR spectra. The correct product was assigned by comparison with NMR data reported by Soós (Ref. 8b). $\mathrm{R}_{f}=0.34\left(10 \% \mathrm{MeOH}\right.$ in $\left.\mathrm{CH}_{2} \mathrm{Cl}_{2}\right) ;[\alpha]^{20}{ }_{\mathrm{D}}=+220.7(c=$ 1.0, $\mathrm{CHCl}_{3}$ ); IR (neat): 3241 (broad), 3076, 2939, 2876, 1622, 1590, 1508, 1474, 1382, 1278, 1226, 1180, $1138 \mathrm{~cm}^{-1}$; ${ }^{1} \mathrm{H} \mathrm{NMR}\left(\mathrm{CDCl}_{3}, 400 \mathrm{MHz}, 40^{\circ} \mathrm{C}\right): \delta 8.62(\mathrm{~d}, J=4.7 \mathrm{~Hz}, 1 \mathrm{H}), 8.02(\mathrm{~d}, J$ $=2.2 \mathrm{~Hz}, 1 \mathrm{H}), 7.93(\mathrm{~d}, J=9.2 \mathrm{~Hz}, 1 \mathrm{H}), 7.87$ (br s, $1 \mathrm{H}), 7.81$ (br s, 2H), 7.47 (d, $J=4.7 \mathrm{~Hz}, 1 \mathrm{H})$, 7.42 (dd, $J=9.2,2.7 \mathrm{~Hz}, 1 \mathrm{H}), 6.35$ (br d, $J=10.7 \mathrm{~Hz}), 5.95$ (ddd, $J=17.3,10.6,6.1 \mathrm{~Hz}, 1 \mathrm{H})$, $5.21(\mathrm{dt}, J=17.4,1.6 \mathrm{~Hz}, 1 \mathrm{H}), 5.13(\mathrm{dt}, J=10.6,1.5 \mathrm{~Hz}, 1 \mathrm{H}), 4.01(\mathrm{~s}, 3 \mathrm{H}), 3.56(\mathrm{~s}, 3 \mathrm{H}), 3.36-$ 3.21 (m, 2H, overlapping signals), $2.99(\mathrm{dd}, J=14.0,10.6 \mathrm{~Hz}, 1 \mathrm{H}), 2.95-2.85(\mathrm{~m}, 2 \mathrm{H}), 2.40-2.30$ $(\mathrm{m}, 1 \mathrm{H}), 1.64-1.49(\mathrm{~m}, 3 \mathrm{H}), 1.26-1.17(\mathrm{~m}, 1 \mathrm{H}), 1.04-0.94(\mathrm{~m}, 1 \mathrm{H}) ;{ }^{13} \mathrm{C} \mathrm{NMR}\left(\mathrm{MeOD}-\mathrm{d}_{4}, 100\right.$ $\mathrm{MHz}): \delta 184.5,159.6,148.5,148.2,148.0,145.2,141.7,134.0\left(\mathrm{q},{ }^{2} J_{\mathrm{CF}}=34.0 \mathrm{~Hz}\right), 131.2,130.2$, 129.3, 124.4, (q, $\left.{ }^{1} J_{\mathrm{CF}}=272.7 \mathrm{~Hz}\right), 123.7,121.7,121.1,121.1,115.2,104.3,61.2,56.5,50.0$, 42.6, 40.2, 28.7, 27.4, 26.5; HRMS $m / z 609.2137\left[\mathrm{C}_{30} \mathrm{H}_{31} \mathrm{~F}_{6} \mathrm{~N}_{4} \mathrm{OS}(\mathrm{M}+\mathrm{H})^{+}\right.$requires 609.2123].

\section{Acknowledgements}

The authors gratefully acknowledge funding from the National Technology Agency of Finland. Special thanks to Ms. Tiia Juhala for conducting the HRMS and CHN analyses, and Mr. Sami Tuomi for preparation of model substrates.

\section{References}

1. Dalko, P. I.; Moisan, L. Angew. Chem. Int. Ed. 2004, 43, 5138. (b) Berkessel, A.; Gröger, H. Asymmetric Organocatalysis; Wiley-VCH: Weinheim, 2005.

2. For first examples of thiourea catalysts in asymmetric synthesis, see Sigman, M. S.; Jacobsen, E. N. J. Am. Chem. Soc. 1998, 120, 4901. 
3. For a review on asymmetric H-bond donor and thiourea catalysis, see: Doyle, A. G.; Jacobsen, E. N. Chem. Rev. 2007, 107, 5716.

4. For a review, see e.g.: Connon, S. J. Chem. Commun. 2008, 2499.

5. Malerich, J. P.; Hagihara, K.; Rawal, V. H. J. Am. Chem. Soc. 2008, 130, 14416.

6. Luo, J.; Xu, L.-W.; Hay, R. A. S.; Lu, Y. Org. Lett. 2009, 11, 437.

7. Bassas, O.; Huuskonen, J.; Rissanen, K.; Koskinen, A. M. P. Eur. J. Org. Chem. 2009, 1340.

8. Li, B.-J.; Jiang, L.; Liu, M.; Chen, Y.-C.; Ding, L.-S.; Wu, Y. Synlett 2005, 603. (b) Vakulya, B.; Varga, S.; Csámpai, A.; Soós, T. Org. Lett. 2005, 7, 1967. (c) McCooey, S. H.; Connon, S. J. Angew. Chem. Int. Ed. 2005, 44, 6367. (d) Ye, J.; Dixon, D. J.; Hynes, P. S. Chem. Commun. 2005, 4481.

9. Derivatization introduced for similar substrates in Knöpfel, T. F.; Zarotti, P.; Ichikawa, T.; Carreira, E. M. J. Am. Chem. Soc. 2005, 127, 9682.

10. For a recent review on the synthetic utility of Meldrum's acid, see: Ivanov, A. S. Chem. Soc. Rev. 2008, 37, 789. and references cited therein.

11. Kleczkowska, E.; Sas, W. Polish J. Chem. 2007, 81, 1457.

12. Okino, T.; Hoashi, Y.; Takemoto, Y. J. Am. Chem. Soc. 2003, 125, 12672. (b) Okino, T.; Hoashi, Y.; Furukawa, T.; Xu, X.; Takemoto, Y. J. Am. Chem. Soc. 2005, 127, 119.

13. Hamza, A.; Schubert, G.; Soós, T.; Pápai, I. J. Am. Chem. Soc. 2006, 128, 13151.

14. Taylor, M. S.; Tokunaga, N.; Jacobsen, E. N. Angew. Chem., Int. Ed. 2005, 44, 6700.

15. The survey contained all thiourea structures containing the $-\mathrm{HNC}(\mathrm{S}) \mathrm{NH}$-moiety similar to the catalysts (numbering over 700) published in the Cambridge Structural Database by September 2009. For an example of trans/trans-structure see CCDC-275454 (Ref. 14), and for a trans/cis-structure, CCDC-685194 (Ref. 7), respectively.

16. For a study on the anomalous acidity, see: Nakamura, S.; Hirao, H.; Ohwada, T. J. Org. Chem. 2004, 69, 4309. (b) Pihlaja, K.; Seilo, M. Acta Chem. Scand. 1969, 23, 3003. (c) Arnett, E. M.; Maroldo, S. L.; Schilling, S. L.; Harrelson, J. A., Jr. J. Am. Chem. Soc. 1984, 106, 6759.

17. Reichardt, C. Solvents and Solvent Effects in Organic Chemistry; 3rd Ed.; Wiley-VCH: Weinheim, 2003, p. 107.

18. Brunner, H.; Bügler, J.; Nuber, B. Tetrahedron: Asymmetry 1995, 6, 1699. (b) Brunner, H.; Schmidt, P. Eur. J. Org. Chem. 2000, 2119.

19. Method for monomethylation of an electron poor aniline: Nagashima, N.; Akamatsu, S.; Kawaminami, E.; Kawazoe, S.; Ogami, T.; Matsumoto, Y.; Okada, M.; Suzuki, K.-I.; Tsukamoto, S.-I. Chem. Pharm. Bull. 2001, 49, 1420.

20. Wang, C.-J.; Zhang, Z.-H.; Dong, X.-Q.; Wu, X.-J. Chem. Commun. 2008, 1431. (b) Zhang, Z.-H.; Dong, X.-J.; Chen, D.; Wang, C.-J. Chem. Eur. J. 2008, 14, 8780.

21. Li, P; Wen, S.; Yu, F.; Liu, Q.; Li, W.; Wang, Y.; Liang, X.; Ye, J. Org. Lett. 2009, 11, 753. 